\title{
Political Risks and Their Economic Effects: Evidence from Egypt
}

\author{
Ashraf Helmy ${ }^{1} \&$ Osama Wagdi ${ }^{2}$ \\ ${ }^{1}$ Faculty of Management, Economics Department, MTI University, Cairo, Egypt \\ ${ }^{2}$ Faculty of Management, Financial Insitutions Department, MTI University, Cairo, Egypt \\ Correspondence: Ashraf Helmy, Economics Department, MTI University, Cairo, Egypt. E-mail: \\ ashraflagoon@gmail.com
}

Received: April 1, 2016

Accepted: April 28, 2016

Online Published: June 25, 2016

doi:10.5539/ijef.v8n7p94

URL: http://dx.doi.org/10.5539/ijef.v8n7p94

\begin{abstract}
This research aims at studying the effect of political changes on Egyptian economy by studying the direct and indirect effect of political risk index and its sub-indicators on number of important variables such as economic growth, employment, exchange rates, Egyptian Exchange main index (EGX30), foreign investment flows, domestic interest rates, and domestic public debt during the time period from 2006 to 2015 using parametric and nonparametric statistical methods. The study concluded that political risk index and its sub-indicators have had varying effects on financial and real investment and other macroeconomic variables in Egypt; and that achieving a successful economic development process cannot be reached without taking into account determinants of political risk.
\end{abstract}

Keywords: sovereign spread, country risk, political risk index, and political risks' sub-indicators

\section{Introduction}

Investment decision, by itself, is not a complicated one, as once we manage to consider all aspects of costs associated with the investment decision and to estimate its expected returns, there will be no difficulty to make a proper decision regarding the proposed investment. The main problem in making any investment decision is the ability to consider all aspects of costs that the investment will expose to. Investment costs can be divided into tangible and intangible costs. Where tangible costs classified as constructional and operational costs; intangible costs include opportunity cost and risk cost. Risk, in general, is defined as all aspects of uncertainty; thus, considering intangible costs will be a relatively harder and complicated task in making any investment decision. The relationship between investment and risk has been developed to the extent that investment decision is considered a risk-return trade off scheme. There are number of models that analyze this relationship such as portfolio theory, capital market line model (Markowitz, 1952), capital assets pricing model introduced by Sharpe (1964) and developed by Lintner (1965) and Black (1972), arbitrage pricing theory (Ross, 1976), Fama and French models (Fama \& French, 1995 \& 2013), and other models that pursuit for risk pricing.

Uncertainty of state condition comes on top of investment risks and represents additional cost to be added to other investment costs (Liu et al., 2013). Uncertainty due to state condition is known as sovereign spread and it reflects the level of country risk. Political risk represents part of sovereign spread in addition to financial and economic risks (Bekaert et al., 2015). The level of political risk is determined by political risk index, which contains number of components in six groups or sub-indicators. The first indicator is related to voice and accountability and it is determined by the extent of military intervention in politics and democratic accountability; the second indicator is related to political stability and absence of violence and it is determined by the extent of government stability, internal and external conflicts, and ethnic and religious tensions; the third indicator is related to government effectiveness and it is determined by bureaucratic quality; the fourth indicator is related to regulatory quality and it is determined by the support provided by the government to the private sector and government intervention in the economy; the fifth indicator is related to rule of law and it is determined by the power of law, litigation's duration and contract enforcement; and finally the sixth indicator is related to control of corruption (International Country Risk Guide [ICRG] and Methodology).

Political risk, as a source of systematic risk, is considered one of the determinants of market risk premium (see: Andrade, 2009), a major determinant of domestic and foreign investment decisions and a variable that able to explain disparities of stocks' returns between different countries (Harvey, 1991), as changes in the level of 
political risk will be reflected on the performance of the stock market in form of fluctuations in stocks' prices, returns and their trading values and volume (Bilson et al., 2002; Dimic et al., 2015). Thus, ignore the important role of the level of political risk while preparing an international portfolio decreases the positive effect of the international diversification of the portfolio (Smimou, 2014).

While interest rates should reflect the risk (default and market risk) associated with lending activities; and, as just mentioned, political risk is part of market risk; then political risks should have their effects on domestic interest rates (Caporale \& Caporale, 2008), as interests have to cover all risk premiums of lending transactions including the one that is related to changes in political status. Then, it is not surprising to notice an increase in interest rates on government securities during periods of political changes, as the level of uncertainty increases during such periods (Huang et al., 2015).

In light of political risk effects on investment decision, stock markets and domestic interest rates, that were discussed earlier, it is expected that the effects of political risk will go further and extend to affect other important economic variables such as economic growth, employment, inflation, exchange rates and domestic public debt. In short, it can be said that political risks may have their effects on macroeconomic goals and development plans.

\subsection{Research Problem}

Political status in Egypt has witnessed severe changes since $25^{\text {th }}$ of January 2011; these changes have had their effects on investment environment in Egypt and directly affected the level of welfare of citizens. Negative effects of political changes in Egypt on investment are explicit, as these changes destroyed the main determinant of any investment decision (domestic and foreign) which is political stability and increase the level of market risk. In addition to the explicit effects of political changes on investment environment, they have had implicit effects on other important economic variables that affect the economic status of Egypt. Where the explicit effects of changes in the level of political risk on investment environment are clear and understandable, the implicit ones on other economic variables and the process of economic development as a whole are not.

\subsection{Research Importance}

Understanding explicit and implicit effects of political changes on the Egyptian economy enables for more accurate decisions and policies during such periods and helps to get-out quickly of such crises, as ambiguity of the impact of these political changes on the economy and unawareness of the sources of threat may aggravate the negative effects of these political changes and/or prolong the time period of these crises. Moreover, political changes represent another important variable to be added to other variables that affect financial instruments in financial markets, cost of doing business, and a variable that should be considered while setting-up economic policies and plans especially during periods of political changes, which is political risk.

\subsection{Research Objective}

Examining the effect of political changes in Egypt on the level of political risk of the country; analyzing the behavior of Egyptian Exchange (represented by its main index EGX30), foreign investment flows, domestic interest rates, domestic public debt, and other macroeconomic variables before, during and after $25^{\text {th }}$ of January 2011 and $30^{\text {th }}$ of June 2013 revolutions, in order to determine the general responsiveness of such variables to these political changes; and finally determining sources of political risk (political risks' sub-indicators) that are responsible for changes in the considered variables and their effects on the process of economic development as a whole.

\subsection{Research Hypotheses}

A. Political changes that have been occurred in Egypt increased the level of political risk of the country.

B. Political changes in Egypt have had significant effect on the performance of Egyptian Exchange.

C. Political changes are the main cause of the inflation of domestic public debt in Egypt.

D. Correlation of political risks' sub-indicators and their effects on different economic variables may explain the failure of the economic development process in Egypt.

\subsection{Research Time Limitation}

This research covers the time period from 2006 to 2015, where this time period has witnessed two revolutions in Egypt ( $25^{\text {th }}$ of January 2011 and $30^{\text {th }}$ of June 2013 revolutions).

\subsection{Research Methodology}

A. Graphical and Tabular Descriptive Techniques 
Arranging, summarizing and presenting data by using tables and suitable graphical techniques, which enable data to produce useful information about the considered variables and make proper decisions based on the information generated.

\section{B. Statistical Analysis}

Using parametric and nonparametric statistical methods that help in analyze the effect of political risk index and its sub-indicators on different variables, determine mutual relationships between variables and measure the effect of these variables on each other.

\subsection{Research Plan}

Section (1): General Framework of the Research.

Section (2): Literature Review.

Section (3): Political Changes and Indicators of Political Risk in Egypt.

Section (4): Political Risk and Egyptian Exchange.

Section (5): Political Risk and Foreign Investment Flows.

Section (6): Political Risk, Domestic Interest Rates and Public Debt.

Section (7): Political Risk and Macroeconomic Goals.

Section (8): Concluding Remarks.

Section (9): Research Recommendations.

\section{Literature Review}

Number of studies are related directly or indirectly to the topic of this study, as there are studies that related to economic effects of political risk and economic conditions, while other studies related to other economic variables covered by this research such as interest rate structure and inflation.

\subsection{Studies Related to Economic Effects of Political Risk}

- Bekaert, Geert, Harvey, Campbell, Lundblad, Christian, Siegel, Stephan, "Political Risk and International Valuation", Journal of Corporate Finance, 2015.

The study found the following main results:

- Political risk reflects, on average, less than a third of the variation of sovereign spreads.

- Adjusting projects' cash flows using sovereign spread substantially overstates discount rate that reflects political risk.

- Heikki Lehkonen and Kari Heimonen, "Democracy, political risks and stock market performance", Journal of International Money and Finance 59, 2015.

The study found the following main results:

- Democracy and political risk do have impact on stock market returns especially for emerging markets.

- The relationship between democracy and political risk is parabolic, where just after a certain level of democracy political risk tends to decrease.

- Stock market returns are negatively related to the level of political risk.

- The movement of international capital flows could reinforce the impact of political turmoil on stock markets.

- Nebojsa Dimic, Vitaly Orlov and Vanja Piljak, "The political risk factor in emerging, frontier, and developed stock markets", Finance Research Letters, 15 (2015).

The study found the following main results:

- Aggregate political risk factor affects stock returns of developed, emerging and frontier markets.

- The effect of political risk's individual components differs according to market classification.

- Government action is the significant common source of political risks in all three market categories.

- For frontier and emerging markets, the main difference relates to the risk of conflict reflected in ethnic tensions.

- Government stability is the source of political risk in frontier stock markets. 
- Tao Huang, Fei Wu, Jing Yu and Bohui Zhang, "International political risk and government bond pricing", Journal of Banking \& Finance, 55, 2015.

The study found the following main results:

- There is a positive and significant relationship between international political risk and government bond yields.

- Yields on government bonds that are issued by countries characterized by stable political systems and strong investor protection are less affected by international political risk.

- Frankie Chau, Rataporn Deesomsak and Jun Wang, "Political uncertainty and stock market volatility in the Middle East and North African (MENA) Countries", Journal of International Financial Markets, Institutions \& Money, 28, 2014.

The study found the following main results:

- Changes in the level of political risk increase the volatility of Islamic indices while their effect on the volatility in conventional markets is insignificant.

- The effect of political changes on the integration of MENA markets with international markets is insignifi8cant.

- Matthias Busse, Carsten Hefeker, "Political risk, institutions and foreign direct investment, European Journal of Political Economy, 23, 2007.

The study found the following main results:

- Government stability, religious tensions, and democratic accountability are highly significant determinants of foreign investment inflows.

- Countries with higher political risk attract less foreign direct investment.

- Political risk and institutional indicators come first when multinational corporations confront decisions about where to invest.

- Olga Kuzmina, Natalya Volchkova and Tatiana Zueva, "Foreign direct investment and governance quality in Russia”, Journal of Comparative Economics, 42, 2014.

The study found the following main results:

- The quality of governance, illustrated by illegal payments, criminal rates, enforcement authorities and corruption, has a considerable effect on the level of investment, in general, and foreign direct investment, in particular.

- Poor quality of governance decrease the ability of countries to attract foreign direct investment, as this decreases the reward to investment.

- Tomasz P. Wisniewski and Saima K. Pathan, "Political environment and foreign direct investment: Evidence from OECD countries", European Journal of Political Economy, 36, 2014.

The study found the following main results:

- Inflation of government spending, especially for military purposes, impedes foreign direct investment inflows.

- Duration of stay in power and totalitarian are negatively related to foreign direct investment inflows.

- Democracy is positively related to foreign direct investment inflows.

- Removing political uncertainty is an essential ingredient in fostering an investment-friendly climate.

- Sandra Aguiar, Luis Aguiar-Conraria, Mohamed Azzim Gulamhussen, Pedro C. Magalhäe, "Foreign Direct Investment and Home-Country Political Risk: The Case of Brazil", Latin American Research Review, Vol. 47, No. 2, 2012.

The study found the following main result:

- The negative relationship between risk and FDI is related to the quality of policy formulation and implementation.

- Enrico C. Perotti and Pieter van Oijen, "Privatization, political risk and stock market development in emerging economies", Journal of International Money and Finance, 20, (2001).

The study found the following main results: 
- Privatization has the power to decrease the tension related to political risk, as privatization strengthens the institutional framework of the country and increase investors' confidence.

- Decreasing the level of political risk is a main source for growth of emerging stock markets.

- Yue-cheong Chan and K.C. John Wei, "Political risk and stock price volatility: The case of Hong Kong", Pacific-Basin Finance Journal, 4, (1996).

- Political news strongly affects stock market volatility.

- Favourable political news positively affects stocks' returns for GARCH-M index and vice versa.

- Political shocks just affect volatility but not the returns of Red-Chip index which makes Red-Chip index a safe haven from political shocks for investors on the Hong Kong economy.

- Eugene. F. Fama and Kenneth R. French, "Business Conditions and Expected Returns on Stocks and Bonds", Journal of Financial Economics, 25, North-Holland, 1989.

The study found the following main result:

- Expected returns on long term securities (common stocks and long-term bonds) have a term or maturity premium that has a clear business-cycle pattern, as these returns tend to increase while moving to trough and to decrease while moving to the peak.

The previous literatures mainly concentrate on economic effects of political risks on stock markets, foreign investments and government securities. The following points are the main conclusion that may serve this research

- The level of political risk has negative effects on stock markets returns and volatilities; and that movements of international capital flows may aggravate the impact of this negative effect.

- Effects of political changes and changes in the level of political risk on stock market are heterogeneous, as they vary across different countries and regions.

- Returns on government securities are positively related to the level of political risk in the country.

- Political risk premium has to be considered while preparing discount factor for investment cash flows.

- Political risk is a significant determinant of foreign investment inflows and the relationship is negative.

\subsection{Studies Related to Economic variables Considered by the Study}

- Adrian Fernandez-Perez, Fernando Fernández-Rodríguez, and Simón Sosvilla-Rivero, "The term structure of interest rates as predictor of stock returns: Evidence for the IBEX 35 during a bear market", International Review of Economics and Finance, 31, 2014.

The study found the following main results:

- There is an increasing role of the yield curve as an indicator of the state of the economy.

- Yield curves have some information content that helps to better forecast the probability of bear markets.

- Andrea Buraschi and Alexei Jiltsov, "Inflation Risk Premium and the expectations hypothesis", Journal of Financial Economics, 75, 2005.

The study found the following main results:

- Inflation risk premium explains $23 \%$ of the time variation in the five-year forward risk premium, and $42 \%$ of the time variation in the ten-year forward risk premium

- Inflation risk premium plays an important role in explaining deviations from the expectations hypothesis of interest rates.

- Risk premium varies with inflation rate volatility.

- Monetary shocks are responsible for $43 \%$ of the volatility of the forward risk premium.

- Inflation risk premium is time varying, as short-term interest rate contains a small inflation risk premium and longer-term interest rate contains a relatively large inflation risk premium.

- Andrew Ang and Monika Piazzesi, "A no-arbitrage vector auto-regression of term structure dynamics with macroeconomic and latent variables", Journal of Monetary Economics, 50, 2003.

- Inflation rates are highly correlated with yields; however, this correlation is high for short-term yields and small for long-term yields. 
- Real activity is weakly correlated with financial assets yields for any maturity.

From the previous studies we can conclude that:

- Domestic interest rate may work as an indicator to the level of risk.

- Inflation rate represents a risk premium to be covered by interest rate.

- Political changes are able to explain fluctuations in domestic interest rates which make domestic interest rate an indicator to country status.

In the light of previous literatures, this research will try to analyze political risk index of Egypt and its sub-indicators in order to study:

- The effect of political risk on number of economic variables that are related to financial and real investment.

- The effect of political risk on the economy as a whole and the process of economic development.

\section{Political Changes and Indicators of Political Risk in Egypt}

As mentioned before, components of political risk index are divided into six sub-indicators. This section examines changes in political risks' sub-indicators as a response to political changes and the mutual relationship between the six sub-indicators that form political risk index in Egypt.

\subsection{Behavior of and Changes in Political Risks'Sub-Indicators}

Figure (1) shows that indicators of political risk have had noticeable changes especially after $25^{\text {th }}$ of January revolution except for government effectiveness and control of corruption indicators which stayed at levels 0.5 and 0.33 respectively during the considered period. The following points summarize the performance of political risks' sub-indicators as a response to political changes in Egypt. An indicator with points near to 1 indicates a relatively very low risk indicator, while an indicator with points near to 0 indicates a relatively very high risk indicator.

- The most vulnerable and risky indicator of political risks' sub-indicators is voice and accountability indicator, as points awarded to this indicator were always below 0.5 and hence it is always located in very high risk zone. Prior to $25^{\text {th }}$ of January (from 2006 to 2010), the indicator recorded 0.4 average points and during revolutions period this average points has been dropped to 0.24 . Voice and accountability indicator recorded average points 0.33 during the whole considered period (2006-2014) with standard deviation 0.09 points.

- In spite that political stability and absence of violence indicator is the less risky indicator of all political risks' sub-indicators before January revolution, as it was located in the range of low risk zone (0.7-0.79) with average points 0.77 prior to $25^{\text {th }}$ of January revolution; however, it suffered a severe decline just after announcing the results of parliamentary elections in 2010, and this downward sloping trend holds during revolution periods (2011-2013), and the indicator moved to moderate risk zone (0.6-0.69) with average points 0.63 and comes in the second place with respect to vulnerability with standard deviation 0.08 points.

- Rule of law indicator occupies the third place with respect to vulnerability with standard deviation 0.06 points, where it moved from moderate risk zone (0.6-0.69) with average points 0.60 prior to January revolution to high risk zone $(0.5-0.59)$ with average points 0.5 during revolution periods.

- Finally, regulatory quality indicator has had a slight drop during revolutions period (2011-2013), but once revolutions period has ended it returned back to its first position. This indicator recorded 0.47 points, in average, during revaluations period and returned back to 0.5 points just after June revolution.
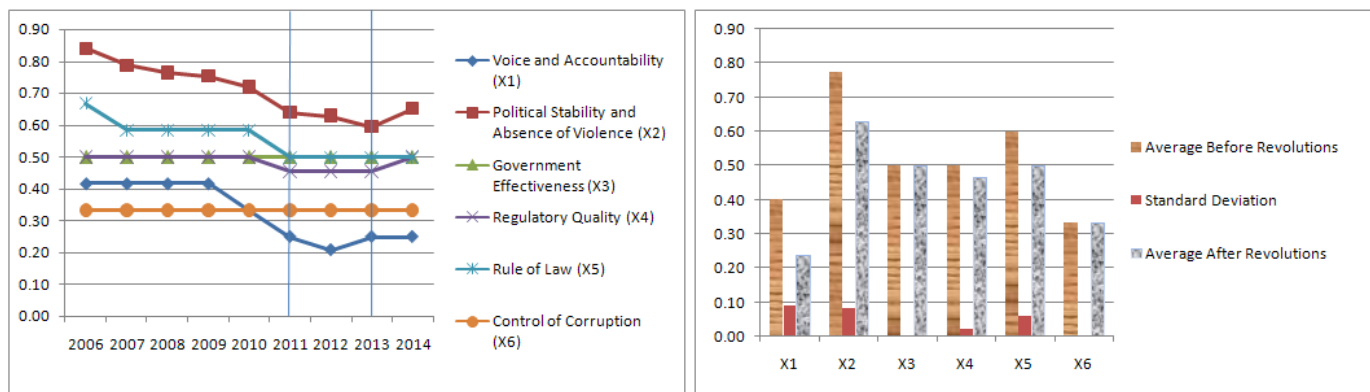

Figure 1. Performance of political risks sub-indicators

Source: Authors calculations based on data extracted from International Country Risk Guide (ICRG) and Indicators. 
It should be noted that $25^{\text {th }}$ of January and $30^{\text {th }}$ of June revolutions did not lead to any improvement to indicators of political risk nor to effective and accountable governance; on contrary, they contributed to deterioration of some of political risks' sub-indicators. Best proof of that is the deterioration of political risk index after the two revaluations, where political risk index recorded 0.44 points, in average, after revolutions period compared to 0.52 points prior to revolutions. Retreating of political risk index by 0.08 points has led to movement of political risk index from high risk zone (0.5-0.59) to very high risk zone (below 0.5). Voice and accountability and control of corruption are the most two risky indicators of political risk index followed by regulatory quality, government effectiveness, rule of law and finally political stability and absence of violence.

Friedman test (non-parametric statistical test) has been used to verify the extent of change in political risk index before, during and after period of revolutions. The test revealed that changes in political risk index are statistically significant at degree of freedom 2 and level of significance $5 \%$. See Table 1.

Table 1. Friedman test of political risk index

\begin{tabular}{cc}
\hline $\mathrm{N}$ & 6 \\
Chi-Square & 7.000 \\
$\mathrm{df}$ & 2 \\
Asymp. Sig. & 0.030 \\
\hline
\end{tabular}

Source: Outputs of Statistical Package for the Social Sciences (SPSS).

Accordingly, political changes that started on $25^{\text {th }}$ of January 2011 have resulted in significant change in the level of political risk of Egypt. In other word, political changes have increased the level of political and country risk.

\subsection{Correlation of Political Risks'Sub-Indicators}

While sub-indicators of political risk will be used as explanatory variables on more than one occasion in this study; then it is useful to determine the mutual relationship between these explanatory indicators.

Pearson correlation test is used to examine the mutual relationship between sub-indicators of political risk index. The test revealed the following findings (see Table 2).

- Voice and accountability indicator $\left(\mathrm{X}_{1}\right)$ is highly and positively correlated with political stability and absence of violence indicator $\left(\mathrm{X}_{2}\right)$ (Pearson correlation is 0.911 , with p-value 0.000$)$; regulatory quality indicator $\left(\mathrm{X}_{4}\right)$ (Pearson correlation is 0.799 , with p-value 0.001 ); and rule of law indicator $\left(\mathrm{X}_{5}\right)$ (Pearson correlation is 0.891 , with p-value 0.000).

- Political stability and absence of violence indicator $\left(\mathrm{X}_{2}\right)$ is highly and positively correlated with regulatory quality indicator $\left(\mathrm{X}_{4}\right)$ (Pearson correlation is 0.761 , with p-value 0.003 ); and rule of law indicator $\left(\mathrm{X}_{5}\right)$. (Pearson correlation is 0.975 , with p-value 0.000 ); while it is negatively correlated with control of corruption indicator $\left(\mathrm{X}_{6}\right)$ (Pearson correlation is -0.731, with p-value 0.005).

- Regulatory quality indicator $\left(\mathrm{X}_{4}\right)$ is highly and positively correlated with rule of law indicator $\left(\mathrm{X}_{5}\right)$ (Pearson correlation is 0.712 , with p-value 0.006 ).

- Rule of law indicator $\left(\mathrm{X}_{5}\right)$ is highly and negatively correlated with control of corruption indicator $\left(\mathrm{X}_{6}\right)$ (Pearson correlation is -0.743 , with p-value 0.004 ).

Table 2. Pearson correlation test of political risks' sub-indicators

\begin{tabular}{cccccc}
\hline Risk Indicators & $\mathrm{X} 1$ & $\mathrm{X} 2$ & $\mathrm{X} 3$ & $\mathrm{X} 4$ & $\mathrm{X} 5$ \\
\hline X2 & 0.911 & & & & \\
P-Value & 0.000 & & & & \\
X3 & $*$ & & & & \\
P-Value & $*$ & 0.761 & $*$ & & \\
X4 & 0.799 & 0.003 & $*$ & & \\
P-Value & 0.001 & 0.975 & $*$ & 0.712 & \\
X5 & 0.891 & 0.000 & $*$ & -0.365 & -0.743 \\
P-Value & 0.000 & -0.731 & $*$ & 0.220 & 0.004 \\
X6 & -0.539 & 0.005 & & & \\
P-Value & 0.057 & & & & \\
\hline
\end{tabular}

Source: Minitab, outcomes of Correlation Test. 
The previous statistical analysis shows that indicators of political risk are highly correlated, which distorts the $t$ test of indicators' coefficients and makes it difficult to determine whether any of political risks' sub-indicators are linearly related to dependent variables, a problem known as multicollinearity in regression analysis. Accordingly, using stepwise method in analyzing the effect of political risks' sub-indicators on different variables will be must.

The high correlation between political risks' sub-indicators increases the responsiveness of political risk index to changes in its sub-indicators. On other word, the mutual relationship between political risks' sub-indicators makes political risk index more vulnerable to any changes in one of its sub-indicators; then, any deterioration in one of political risks' sub-indicators may lead to a severe deterioration in the whole political risk index. On the bright side, any improvement in one of political risks' sub-indicators may lead to further improvement in political risk index.

\section{Political Risk and Egyptian Exchange}

\subsection{Historical Overview of the Performance of Main index of Egyptian Exchange (EGX30)}

It becomes known that high level of political risk has a considerable negative effect on stock markets whether they are emerging or developed markets (Dimic et al., 2015), which holds true for the case of Egyptian Exchange. Political changes that started on $25^{\text {th }}$ of January 2011 have had their effects on the Egyptian Exchange, in general, and its main index EGX30, in particular. Figure 2 illustrates historical overview of the performance of EGX30 index since its birth in 1998 until year 2015. The index reached its peak in 22/4/2008 with a record of 12039 points, after that and as a response to changes in tax policies, rumors regarding tax accounting for transactions in securities and global financial crisis 2008, the performance of EGX30 index started to deteriorate severely. In 2009, Egyptian Exchange started to recover and EGX30 index reached another peak in 2010 with a record of 7693.38 points. In early 2011, the index started to take a downward sloping trend again this time the reason was the outbreak of the Arab spring, in general, and the $25^{\text {th }}$ of January revolution, in particular. In this regard, trading transactions in Egyptian stock market have been suspended from the $27^{\text {th }}$ of January 2011 till $23^{\text {rd }}$ of March 2011, which was as a warning of the departure of Egyptian Exchange main index (EGX30) of emerging markets index.

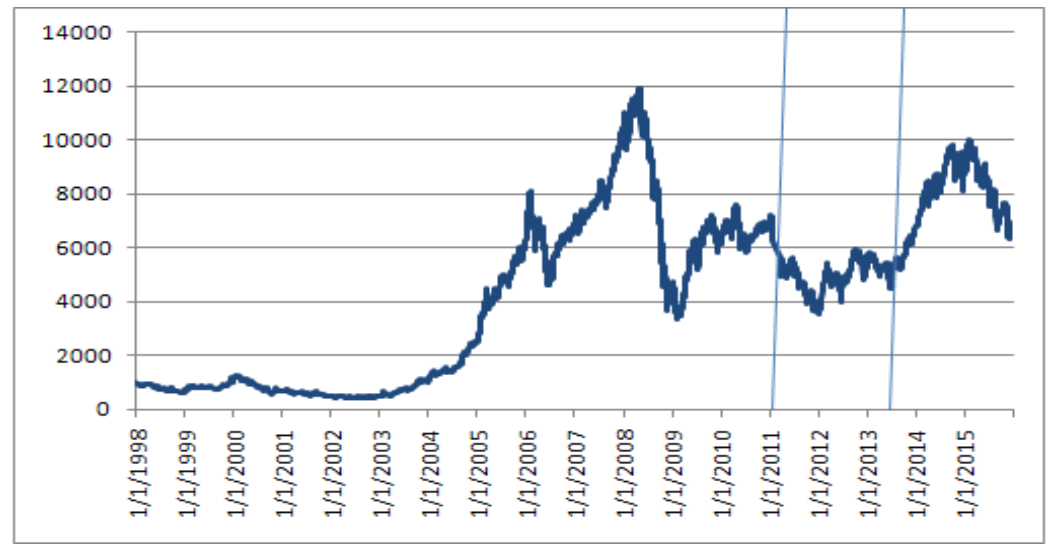

Figure 2. The performance of main index of Egyptian Exchange (EGX30)

Source: Authors calculations based on data extracted from Egyptian Exchange.

Figure 3 illustrates a detailed analysis of EGX30 daily returns during the considered time period (2006-2015). The analysis revealed that political changes and the accompanying rise in the level of political risk have had the greatest negative impact on EGX30 daily returns, as the worst average daily rate of return on EGX30 index was $-0.308 \%$ in 2011 , followed by the one resulted from the impact of global financial crisis in 2008 , where the average daily rate of return on EGX30 was $-0.306 \%$.

On the other side, average daily rate of return on EGX30 achieved positive rates in 2009 and $2010(0.143 \%$ and $0.065 \%$ respectively), which could be attributed to the ability of the Egyptian economy, in general, and the banking system, in particular, to absorb the negative effects of the global financial crisis and to solidify against global crisis 2008, as a result of reform policy of Egyptian banking system in 2003. 
After the election of a new president in 2012, average daily rate of return on EGX30 started to increase and reached $0.184 \%$; however, it declined again in 2013 in the wake of $30^{\text {th }}$ of June revolution to $0.097 \%$. In light of relative political stability achieved after June revolution, average daily rate of return on EGX30 increased to $0.121 \%$ in 2014 and reached a peak record of 9811.4 points in 10/1/2014.

In 2015, a global financial crisis emerged again as a result of Chinese stock bubble, currencies war, and the collapse of oil prices, and again average daily rate of return on EGX30 decreased by $22 \%$ and turn to be negative at $-0.088 \%$.

As for EGX30 risk, it can be analyzed based on number of indicators such as standard deviation, skewness and kurtosis. The coefficient of kurtosis reached 5.3 in 2011 indicating an increase in the level of risk, which may be attributed to changes in political status. From Figures 2 and 3, it can be said that kurtosis coefficient reflects the performance of average daily return on EGX30, as it recorded another high number 6.8 in year 2008 when average daily return on EGX30 was negative due to negative impacts of the global financial crisis on Egyptian Exchange. After June revolution, the coefficient of kurtosis decreased which indicates that the negative impact of political changes on Egyptian Exchange has been retreated.

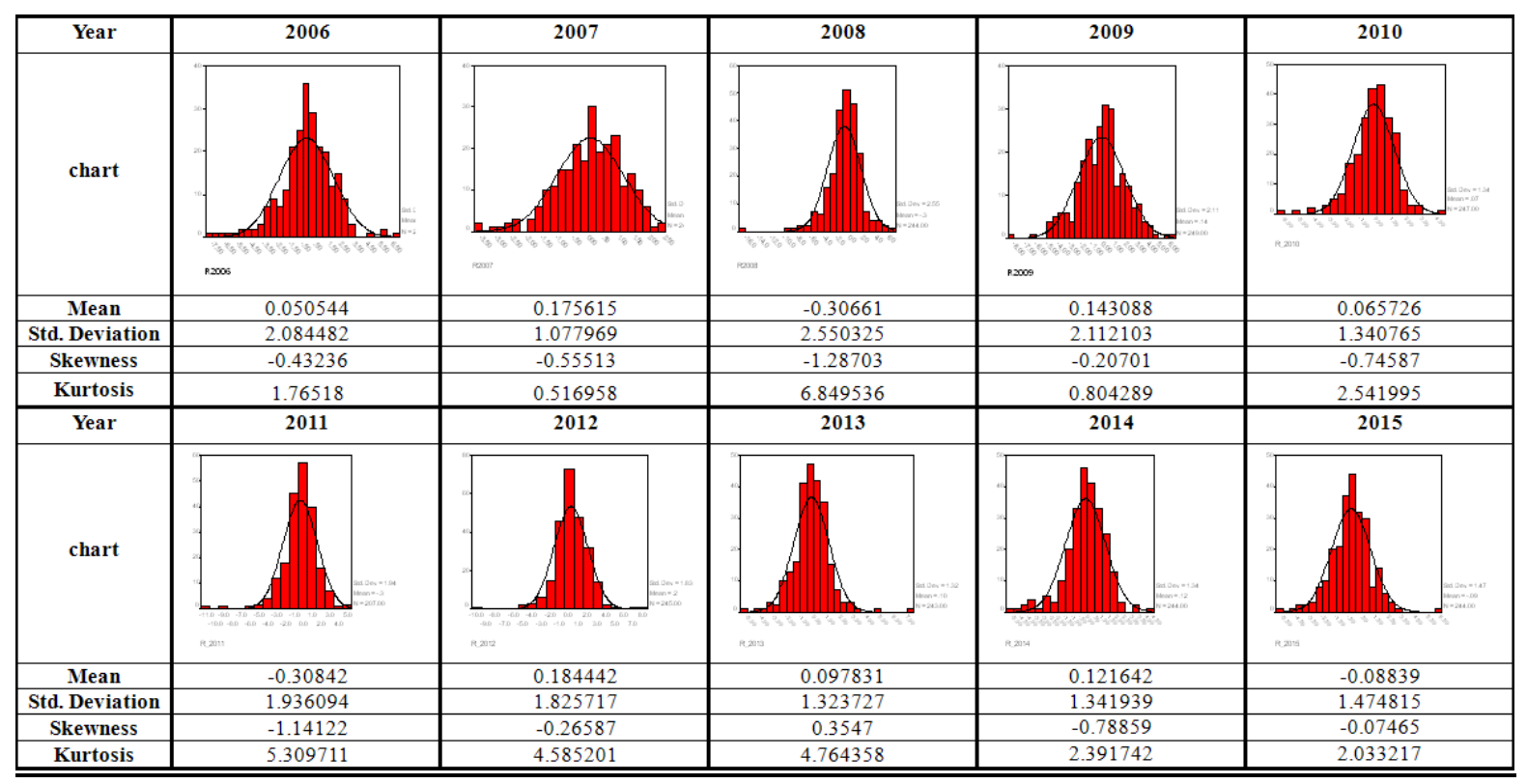

Figure 3. Histogragms of average daily returns on EGX30

Source: Authors calculations based on data extracted from Egyptian Exchange.

\subsection{Political Changes and Returns on EGX30}

A regression analysis has been developed to verify the effect of political changes on EGX30 daily and annual returns. Political risks' sub-indicators will act as independent variables, while returns on EGX30 act as the dependent variable. The statistical analysis revealed that the relationship between daily returns on EGX30 and political risks' sub-indicators is statistically insignificant; and that of the six sub-indicators of political risk index there is only one that is statistically significant with annual return on EGX30. Control of corruption $\left(\mathrm{X}_{6}\right)$ has a negative relationship (coefficient -1060 ) with annual returns on EGX30 [R-Sq $=45.2 \% \mathrm{R}-\mathrm{Sq}(\mathrm{adj})=40.3 \%, \mathrm{~F}$ statistic is 9.08 with p-value 0.012]. See Appendix 1.

In spite that this finding is a confusion one; however, it is comparable with the finding of Egger and Winner (2005), as they found a positive relationship between the level of corruption and foreign direct investment and they suggest that corruption may act as a helping hand to encourage foreign direct investment inflows.

\subsection{Examine the Variation and Homogeneity of Average Daily Returns on EGX30}

Onaway ANOVA test has been used to examine the significant of variations of Egyptian Exchange returns as a response to changes in the level of political risk. See Table 3. 
Table 3. ANOVA test statistics of EGX30 daily returns

\begin{tabular}{lcccc}
\hline EGX30-Returns & Sum of Squares & df & Mean Square & F \\
\hline Between Groups & 5.026 & 2 & 2.513 & 0.806 \\
Within Groups & 7505.843 & 2407 & 3.118 & 0.447 \\
Total & 7510.869 & 2409 & & \\
\hline
\end{tabular}

Source: Outputs of Statistical Package for the Social Sciences (SPSS).

F test, at a degree of freedom 2 and level of significance 0.05 , revealed that average daily return on EGX30 did not respond to changes in the level of political risk, which goes in line with the finding of Lehkonen and Heimonen (2015), as their study indicated that the effect of political risk on stock returns fades gradually.

Test of Homogeneity of Variances has been used to examine the significant of homogeneity of average daily return on EGX30 as a response to changes in the level of political risk. See Table 4.

Table 4. Homogeneity test statistics of EGX30 daily returns

\begin{tabular}{lcccc}
\hline & Levene Statistic & df1 & df2 & Sig. \\
\hline EGX30-Returns & 15.761 & 2 & 2407 & 0.000 \\
\hline
\end{tabular}

Source: Outputs of Statistical Package for the Social Sciences (SPSS).

Levene statistic is significant, at level of significance 0.05 , which indicates that stocks returns as a response to changes in the level of political risk are heterogeneous. What is worth mentioning that this finding is consistent, to a large extent, with the finding of (Voth, 2002), (Apergis, 2015) and (Vortelinos \& Saha, 2016), as their studies indicated that the effect of political risk on stocks is volatile and intermittent.

\subsection{Examine the Variation and Homogeneity of Traded Stocks Value}

Again, Onaway ANOVA test has been used to examine the significant of variations of traded stocks value as a response to changes in the level of political risk. See Table 5.

Table 5. ANOVA test statistics of EGX30 traded value

\begin{tabular}{lcrrr}
\hline EGX30-Traded Value & Sum of Squares & df & Mean Square & F \\
\hline Between Groups & $1.8 \mathrm{E}+20$ & 2 & $9.1 \mathrm{E}+19$ & 588.336 \\
Within Groups & $3.7 \mathrm{E}+20$ & 2407 & $1.5 \mathrm{E}+17$ & 0.000 \\
Total & $5.6 \mathrm{E}+20$ & 2409 & & \\
\hline
\end{tabular}

Source: Outputs of Statistical Package for the Social Sciences (SPSS).

F test, at a degree of freedom 2 and level of significance 0.05 , revealed that value of traded stocks did respond to changes in the level of political risk.

Test of Homogeneity of Variances has been used to examine the significant of homogeneity of stocks traded value as a response to changes in the level of political risk. See Table 6.

Table 6. Homogeneity test statistics of EGX30 traded value

\begin{tabular}{lcccl}
\hline & Levene Statistic & df1 & df2 & Sig. \\
\hline EGX30-Traded Value & 162.483 & 2 & 2407 & 0.000 \\
\hline
\end{tabular}

Source: Outputs of Statistical Package for the Social Sciences (SPSS).

Levene statistic value is significant, at level of significance 0.05 , which indicates that stocks traded value as a response to changes in the level of political risk are heterogeneous. This illustrates that value of traded stocks responds to the status of the economy, in general, and financial market status, in particular.

A regression analysis has been developed to verify the effect of political changes on the value of traded stocks. This time, political risks' sub-indicators will act as independent variables, while values of traded stocks act as the 
dependent variable. The statistical analysis has ascertained that values of traded stocks respond to the level of political risk and that voice and accountability $\left(\mathrm{X}_{1}\right)$ and control of corruption $\left(\mathrm{X}_{6}\right)$ sub-indicators are statistically significant and positively related to values of traded stocks $[\mathrm{R}-\mathrm{Sq}=86.4 \% \mathrm{R}-\mathrm{Sq}(\mathrm{adj})=83.6 \%$, F statistic is 36.66 with p-value 0.000]. See Appendix 2.

Foreign traders (Arabs and non-Arabs) respond to the same two political risks' sub-indicators, as there is a significant statistical and positive relationship between value of traded stocks by foreigners and both voice and accountability $\left(\mathrm{X}_{1}\right)$ and control of corruption $\left(\mathrm{X}_{6}\right)$ sub-indicators. See Appendix 3 and 4.

Egyptian traders also respond to changes in the level of political risk; however, they concern with regulatory quality and the level of corruption, as changes in values of traded stocks by Egyptians are positively related to regulatory quality $\left(\mathrm{X}_{4}\right)$ and the control of corruption $\left(\mathrm{X}_{6}\right)$ sub-indicators. See Appendix 5.

\section{Political Risk and Foreign Investment Flows}

\subsection{Behavior of Foreign Investment Flows}

Figure 4 shows that both net flows of foreign direct and indirect (portfolio) investment have been retreated with the outbreak of January revolution; however, the decline in net flows of portfolio investment was harsher relative to the decline in net flows of foreign direct investment, as net flows of portfolio investment decreased by $132.4 \%$ and moved to the negative zone at -2551 million US dollars in 2011 compared to a decrease by $67.6 \%$ in foreign direct investment net flows.

After January revolution, net flows of portfolio investment continued to decline and reached -5025 million US dollars in 2012, with a decline of $97 \%$, while foreign direct investment net flows increased by $82 \%$ in the same year (from 2188 in 2011 to 3982 million US dollars in 2012).

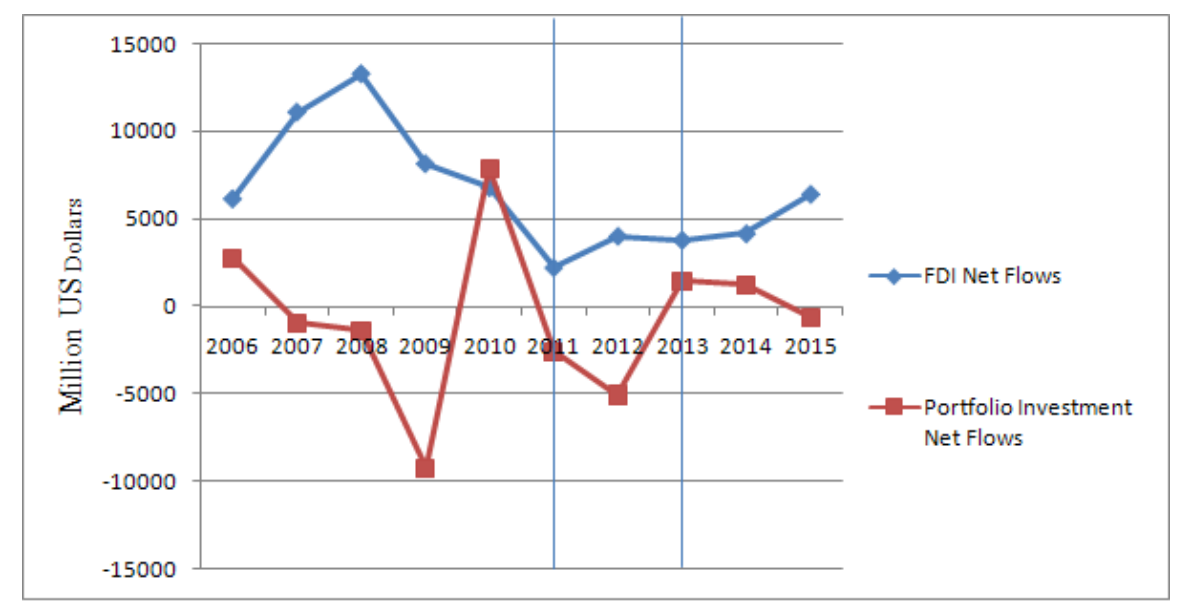

Figure 4. Foreign investment net flows

Source: Ministry of Finance, Monthly Financial Report, different editions.

The previous characteristics of both foreign direct and portfolio investment make foreign direct investment more desirable over portfolio investment especially for implementation of development plans in developing countries. Changes in both types of foreign investment net flows illustrate that portfolio investment is relatively more vulnerable, as standard deviation of changes in portfolio investment net flows during the considered period was 7686 million US dollars compared to 3178 million US dollars for foreign direct investment. Accordingly, Matthias Busse and Carsten Hefeker (2007) call for not to rely on portfolio investment for financing development plans, as this may lead to financial and economic crises, and they advise countries to do their best to attract foreign direct investment. Figure 5 illustrates changes in net flows of foreign direct and portfolio investment. 


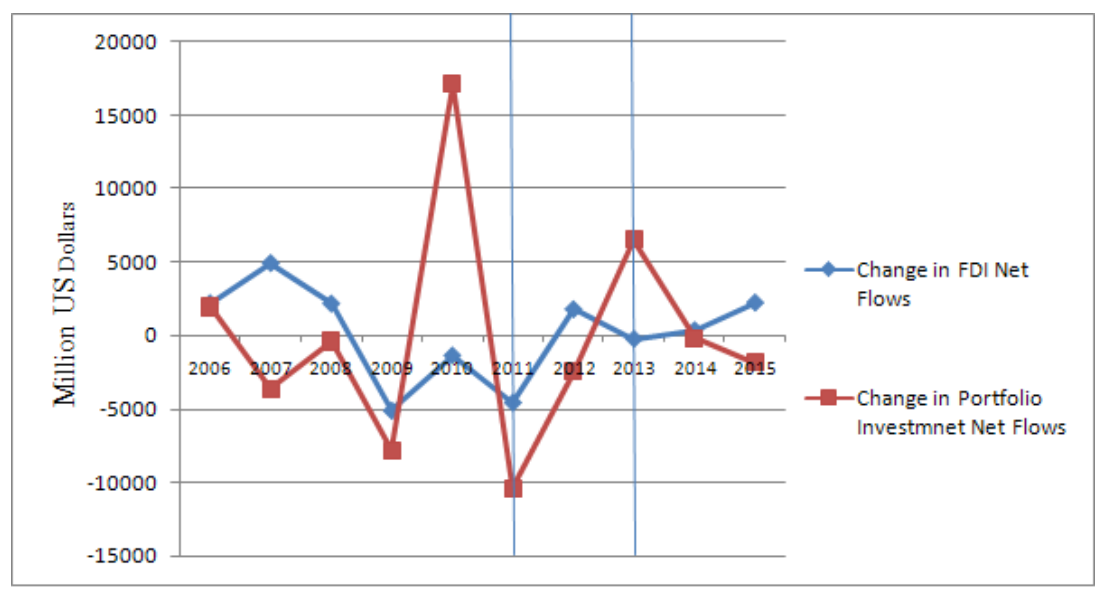

Figure 5. Changes in foreign investment net flows

Source: Ministry of Finance, Monthly Financial Report, different editions.

\subsection{Political Risk Index and Foreign Investment Flows}

The effect of changes in political risk index on foreign investment flows will be examined by using regression analysis in which sub-indicators of political risk index act as independent variables or explanatory variables and foreign direct and portfolio investment net flows and their changes act as dependent variables.

The statistical analysis revealed the followings:

- There is a statistical significant positive relationship between foreign direct investment net flows and both voice and accountability indicator $\left(\mathrm{X}_{1}\right)$ and control of corruption indicator $\left(\mathrm{X}_{6}\right)[\mathrm{R}-\mathrm{Sq}=80.2 \% \mathrm{R}-\mathrm{Sq}(\mathrm{adj})=$ $76.2 \%$, F statistic is 20.24 with p-value 0.000]. See Appendix 6.

- The statistical relationship between changes in foreign direct investment net flows and political risks' subindicators is insignificant $[\mathrm{R}-\mathrm{Sq}=10 \% \mathrm{R}-\mathrm{Sq}(\mathrm{adj})=0 \%, \mathrm{~F}$ statistic is 0.16 with p-value 0.971]. See Appendix 7.

- The relationship between portfolio investment net flows and political risks' sub-indicators is statistically insignificant $[\mathrm{R}-\mathrm{Sq}=47.3 \% \mathrm{R}-\mathrm{Sq}(\operatorname{adj})=9.7 \%$, F statistic is 1.26 with p-value 0.377]. See Appendix 8 .

- The regression analysis of changes in portfolio investment net flows and political risks' sub-indicators confirms the previous statistical finding, as the relationship between changes in portfolio investment net flows and political risks' sub-indicators is statistically insignificant $[\mathrm{R}-\mathrm{Sq}=64.0 \% \mathrm{R}-\mathrm{Sq}(\mathrm{adj})=38.3 \%, \mathrm{~F}$ statistic is 2.49 with p-value 0.133]. See Appendix 9.

According to the previous statistical findings it can be said that:

- Decreasing the extent of military intervention in politics, prevailing of democracy, and controlling corruption are all attractive elements for foreign direct investment in Egypt; however, controlling corruption has a greater impact on attracting foreign direct investment, as coefficient of controlling corruption consists of 6 digits (103489), while coefficient of voice and accountability consists of 5 digits (34492).

- In spite that net flows of foreign direct investment respond to changes in political risks' sub-indicators; however, changes in net flows of foreign direct investment do not. In other word, it can be said that changes in foreign direct investment is relatively inelastic to changes in political risks' sub-indicators. This is due to the difficulty of withdrawal of foreign direct investment from the economy.

- The nature and characteristics of portfolio investment make net flows of portfolio investment and their changes irrelevant to changes in political risks' sub-indicators, as this type of capital flows is highly vulnerable, pursuits just high and quickly profit, and based mainly on the perception of investors rather than changes in political status and level of political risk.

\section{Political Risk, Domestic Interest Rates, and Public Debt}

\subsection{Attitude of Domestic Interest Rates as a Response to Political Changes}

Interest rates are usually related to the level of risk, according to this fact trying to figure out a relationship between domestic interest rates and risks resulting from political changes in Egypt will be useful not just to understand the direct effect of political changes on domestic interest rates, but also to understand the indirect 
effect of political changes on other variables that are related to domestic interest rates such as consumption, saving, investment, and public debt.

Domestic interest rates will be represented in this section by six interest rates on different financial instruments, for different maturities and from different sources: Central Bank of Egypt discount rate, interest rate on short-term loans, interest rate on short-term deposits, interest rate on 3 months treasury bills, interest rate on investment certificates (long-term deposits), and interest rate on deposits at post-office (small savers short-term deposits).

Table 7 and Figure 6 show that the trend of maximum, minimum and average domestic interest rates is negative (downward sloping) just before $25^{\text {th }}$ of January 2011 revolution and then it turns to be positive (upward sloping) just after January revolution. The upward tendency of domestic interest rates holds until the $30^{\text {th }}$ of June 2013 revolution; and then, it turns to decline again and follows a downward sloping trend just after June revolution. What is worth mentioning that domestic interest rates in Egypt responded to global financial crisis 2007 as well, as it declined during years 2007 and 2008 as a response to effects of global financial crisis on the Egyptian economy. Global financial crisis 2007 negatively affected stocks prices and positively affected the public budget deficit as a result of the decrease in government expenditures on subsidized imported goods (Sultan Abou Ali, 2008). However, responsiveness of domestic interest rates to political changes is relatively stronger than its responsiveness to financial crises, where the slope of average domestic interest rate line is much steeper during periods of revolutions (1.19) and political stability (-1.11) relative to the period of financial crisis $(-0.17)$.

Table 7. Behavior of domestic interest rates

\begin{tabular}{lccccc}
\hline \multicolumn{5}{c}{ Before Revolutions (\%) } \\
\hline Max Interest & 2006 & 2007 & 2008 & 2009 & 2010 \\
Min Interest & 12.71 & 12.64 & 12.22 & 12.39 & 11.35 \\
Range & 6.53 & 6.01 & 6.09 & 7.03 & 5.97 \\
Average & 6.18 & 6.63 & 6.13 & 5.36 & 5.38 \\
Standard Deviation & 9.34 & 9.3 & 9.13 & 9.84 & 9.04 \\
\hline & 1.98 & 2.15 & 2.24 & 1.79 & 1.79 \\
\hline & After Revolutions (\%) & & 2015 \\
\hline Max Interest & 2011 & 2012 & 2013 & 11.71 \\
Min Interest & 10.84 & 13.38 & 13.35 & 7.92 & 6.99 \\
Range & 6.52 & 7.26 & 7.77 & 4.73 & 4.72 \\
Average & 4.32 & 6.12 & 5.58 & 9.64 & 9.62 \\
Standard Deviation & 9.09 & 10.28 & 10.75 & 1.75 & 1.79 \\
\hline
\end{tabular}

Source: Authors calculations based on data extracted from Ministry of Finance, The Financial Monthly Report, different editions.

Standard deviation of average domestic interest rates could be a good indicator of volatility of domestic interest rates. Figure 6 shows that standard deviation of domestic interest rates recorded relatively high rates during periods of internal and external shocks. For instance, during period of global financial crisis (an external shock) 2007 and 2008 standard deviation of domestic interest rates recorded $2.15 \%$ and $2.24 \%$ respectively and then decreased to $1.79 \%$ in 2009 and 2010. On another occasion, standard deviation of domestic interest rates increased again to $2.15 \%$ and $2.12 \%$ in 2012 and 2013, the increase in standard deviation this time is attributed to status of political instability in Egypt. Thus, behavior of standard deviation of average domestic interest rates indicates that interest rates are vulnerable (elastic) to internal and external shocks.

The attitude of average domestic interest rates and its standard deviation in Egypt is consistent with the finding of Andrea and Alexei, as they assert that the price of risk is state-dependent and can explain the conditional volatility of interest rates (Andrea Buraschi \& Alexei Jiltsov, 2005). 

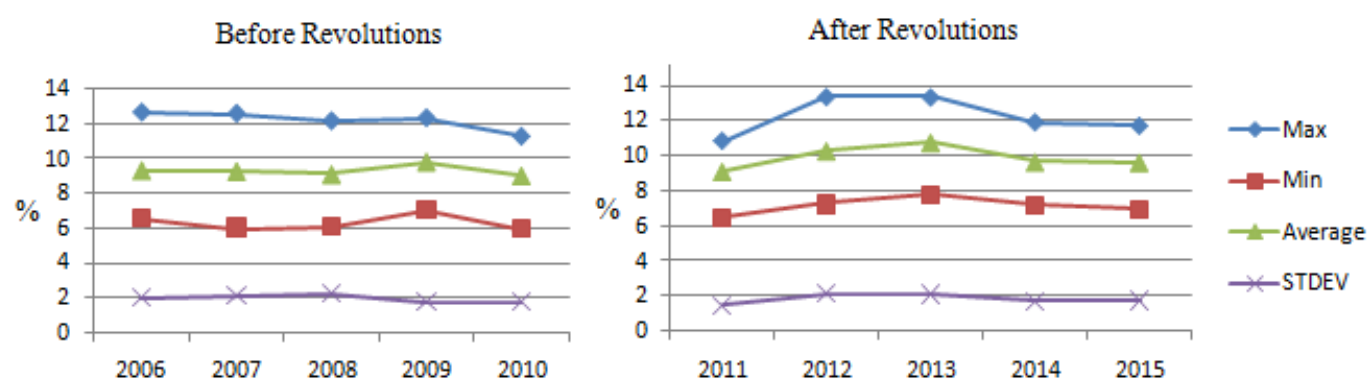

Figure 6. Attitude of domestic interest rates before and after revolutions

Source: Table 1.

\subsection{Political Changes and Components of Domestic Interest Rates Structure}

The behavior of domestic interest rates can be explained more precisely by analyzing the performance of their main components during periods of noticed political changes. Figure 7 shows the development of six interest rates with different maturities and types that form domestic interest rates structure in Egypt. Number of points can be excluded from this figure:

- The most volatile interest rate is interest rate on investment certificates (relatively long-term deposits), as standard deviation of average interest rate on investment certificates increased by 0.7 after $25^{\text {th }}$ of January revolution (1\%-0.3\%). This may be attributed to the contractionary monetary policy adopted by Central Bank of Egypt to contain high inflation rates and reduce speculation operations on US dollar, with expectations of sustained high prices in the future and continuous devaluation of the Egyptian pound.

- The most responsive interest rate to political changes is the one on treasury bills (short-term government bonds), as average interest rate on 91 days treasury bills increased by $2.73 \%$ after $25^{\text {th }}$ of January revolution $(11.9 \%-9.1 \%)$. This may be attributed to the increase in the level of political risk as a result of political changes and the consequent increase in lending risk.

- Average interest rate on short-term deposits at post-office decreased by $-0.53 \%$ after $25^{\text {th }}$ of January revolution (8.83\%-9.5\%). This tendency of short-term interest rate is consistent with Taylor rule, which implies that short-term interest rate carries low inflation risk premium (Taylor, 1993).

- In spite that average interest rate on short-term deposits (3 months deposits) increased after $25^{\text {th }}$ of January revolution; however, it still lower than average interest rate on deposits at post-office.

- Average interest rate on short-term loans decreased after $25^{\text {th }}$ of January revolution, this may be attributed to the severe recession period that the Egyptian economy has witnessed just after the revolution and the consequent decrease in the level of investments. In other ward, short-term interest rate on loans is designed to correct aggregate output deviations, which is also consistent with Taylor rule.

Regression analysis of components of domestic interest rates (as dependent variables) and political risk index components or indicators (as independent variables) may accurately explain responsiveness of domestic interest rates to political changes. Of the six types of interest rates that form domestic interest rate structure and the six sub-indicators of political risk index there are only three interest rates (interest rate on short-term loans, interest rate on deposits at post office, and interest rate on treasury bills) of a significant statistical relationship with only two sub-indicators of political risk index (political stability and absence of violence; and control of corruption).

- There is a direct relationship between interest rate on short-term loans and political stability and absence of violence $[\mathrm{R}-\mathrm{Sq}=71 \% \mathrm{R}-\mathrm{Sq}(\mathrm{adj})=68 \%$, F statistic is 26.95 with p-value 0.000$]$. This can be explained as during periods of political stability demand for investment increases and generates upward pressures on loans' interest rates. See Appendix 10.

- There is an inverse strong relationship between interest rate on deposits at post office (short-term deposits) and the ability to control corruption [R-Sq $=82.5 \% \mathrm{R}-\mathrm{Sq}(\mathrm{adj})=80.9 \%$, F statistic is 51.9 with p-value 0.000 ]. This might be related to the positive effect of containing corruption on small savers' incomes and public budget deficit. See Appendix 11.

- There is an inverse relationship between interest rate on treasury bills and political stability and absence of 
violence $[\mathrm{R}-\mathrm{Sq}=59.6 \% \mathrm{R}-\mathrm{Sq}(\mathrm{adj})=55.91 \%, \mathrm{~F}$ statistic is 16.2 with $\mathrm{p}$-value 0.002$]$. This is a logical finding as with high degree of political instability and violence the risk of lending to country increases and interest rates on government securities increase as well. In other word, interest rates on government securities are function of risk premiums that mainly result from political instability. See Appendix 12.

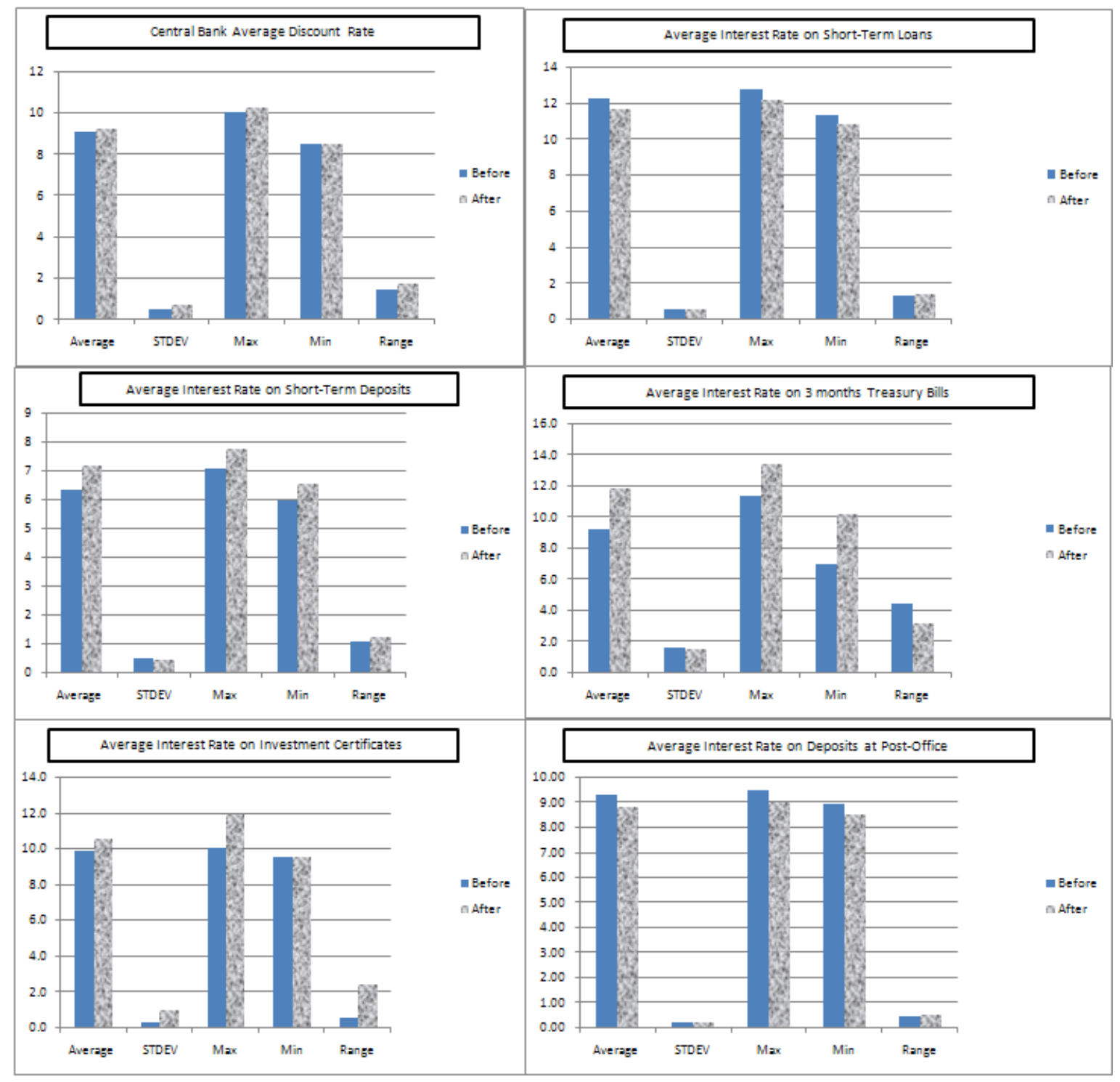

Figure 7. Development of interest rates that form domestic interest rate structure

Source: Authors calculations based on data extracted from Ministry of Finance, The Financial Monthly Report, different editions.

\subsection{Domestic Public Debt and Political Changes}

Figure 8 shows that domestic public debt has been aggravated since January revolution, as domestic public debt was 755.3 billion Egyptian pounds in 2010; and then increased to 2116.3 billion Egyptian pounds in 2015. This means that domestic public debt has increased by $180 \%$ during period of revolutions. In spite the trend of domestic public debt before revolutions was positive; however, the change in domestic public debt was in average 77.2 billion Egyptian pounds during the time period (2006-2010); and then increased to 245.5 billion Egyptian pounds during the time period (2011-2015), with an increase of 218\%. The only logical explanation for this significant inflation in domestic public debt is the occurrence of two successive revolutions in a short time period and their negative consequences on the political status in Egypt.

A regression analysis between domestic public debt (as a dependent variable) and political risk sub-indicators (as 
explanatory variables) confirmed the validity of this suggested explanation. The analysis found a statistically significant negative relationship between domestic public debt and political stability and absence of violence $((\mathrm{R}-\mathrm{Sq}=82.1 \% \mathrm{R}-\mathrm{Sq}(\operatorname{adj})=80.5 \%, \mathrm{~F}$ statistic is 50.61 with p-value 0.000). See Appendix 13 .

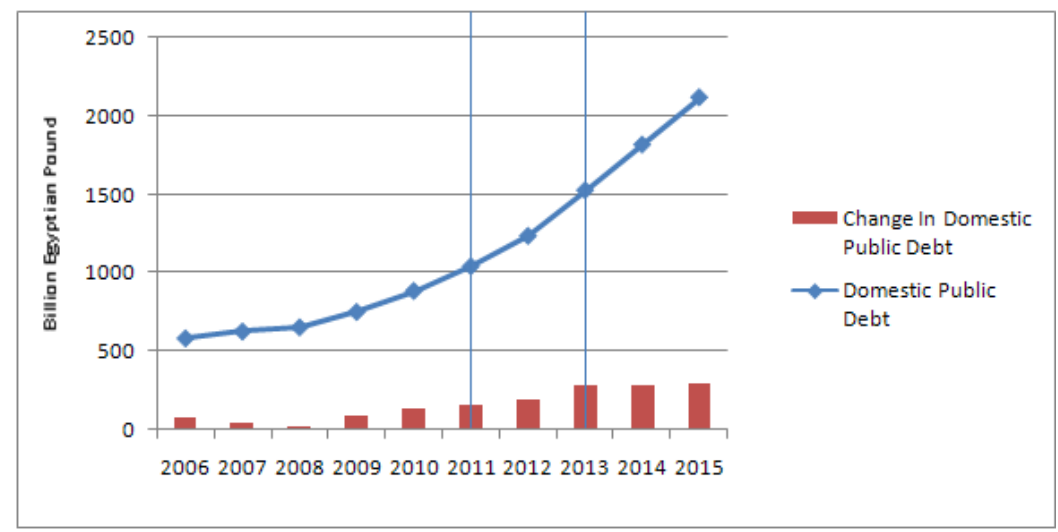

Figure 8. Development of domestic public debt in Egypt

Source: The Egyptian Cabinet, Information and Decision Support Center.

Unfortunately, the problem of aggravation of domestic public debt does not come alone, as it always associated with another problem which is aggravation of debt service payments (interest on debt).

Figure 9 shows that interest payments on domestic public debt was 69.5 billion Egyptian pounds in 2010; and then this number increased by $171 \%$ and climbed to 188.3 billion Egyptian pounds in 2015 . The change in interest payments on domestic debt recorded in average 8 billion Egyptian pounds per year during the time period that preceded January revolution (2006-2010); then this figure has tripled during the period of revolutions and recorded in average 23.8 billion Egyptian pounds per year during the time period (2011-2015).

Actually, the massive increase in interest payments on domestic public debt is attributed to two factors; the increase in the level of domestic public debt and the increase in interest rate on government securities. While domestic public debt and interest rate on government securities are both linked to political changes and the level of political risk, as confirmed earlier, then finding a relationship between interest payments on domestic debt and political changes will be a logical one. This has been proven statistically, as there is a statistically significant negative relationship between interest payments on domestic public debt and political stability and absence of violence $[\mathrm{R}-\mathrm{Sq}=77.8 \% \mathrm{R}-\mathrm{Sq}(\operatorname{adj})=75.7 \%, \mathrm{~F}$ statistic is 38.48 with $\mathrm{p}$-value 0.000]. See Appendix 14 .

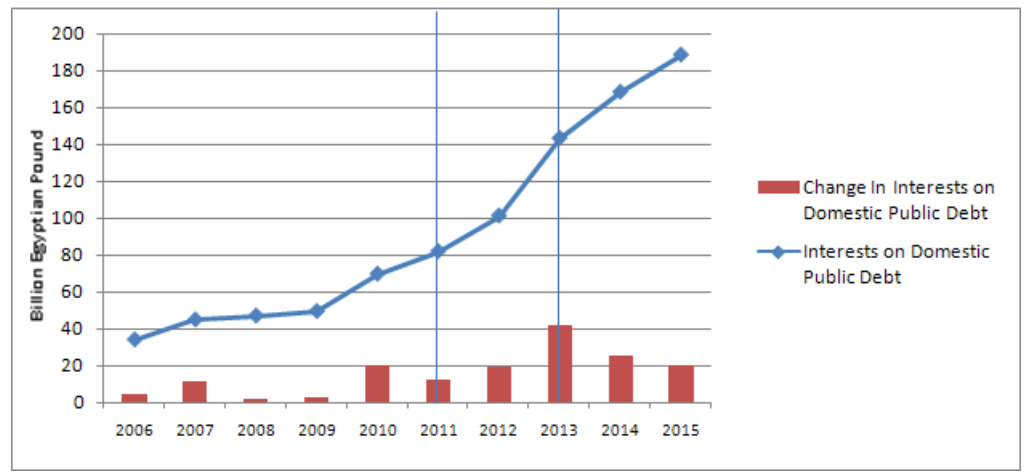

Figure 9. Development of interest on domestic public debt in Egypt

Source: The Egyptian Cabinet, Information and Decision Support Center.

\section{Political Changes and Macroeconomic Goals}

Figure 10 shows that, the sharp decline in the rate of economic growth occurred in 2011, the most reasonable explanation for that is the occurrence of $25^{\text {th }}$ of January revolution. This low rate of economic growth continues 
during period of political instability below its potential growth rate, and it began to improve only after the $30^{\text {th }}$ of June revolution and the partial regaining of political stability after presidential election in 2014.

With economic growth rates that are below their potential rates it was natural for the unemployment rate to increase. In spite the improvement in economic growth rate did not manage to change the upward trend of unemployment rate; however, the slope of this trend became more falter after this improvement (the slope of unemployment curve was 3 in 2011, 0.7 in 2012, 0.5 in 2013, 0 in 2014 and 0.3 in 2015).

Responsiveness of inflation rate to changes in political status in Egypt was not clear, as fluctuations of inflation rates are not related and can't be explained by changes in political status.

In contrast, it is clear that changes in exchange rates are due to political changes, as exchange rates were relatively stable tell 2010 and then the upward trend of exchange rates starts just after $25^{\text {th }}$ of January revolution. This upward sloping trend continues even after presidential election in 2014, where the so-called Arab Spring has destroyed the sources of foreign currencies for most Arab countries. For Egypt, political instability has destroyed one important source of foreign exchange which is tourism. Tourism returns, before periods of revolutions (2006-2010), represented in average 24.5\% of total exports; and after revolutions (2011-2014) this number decreased to $18 \%$, where number of tourists (arrivals) decreased in average by $14 \%$ from year 2011 to 2014 (World Bank, World Development Indicators). In addition, the returns of tourism sector decreased by 28.3\% in average after year 2010, as tourism returns recorded 1024.7 million US dollars in average during the time period (2006-2010) and this number decreased to 734.5 million US dollars in average during the time period (2011-2014) (The Egyptian Cabinet, Information and Decision Support Center).

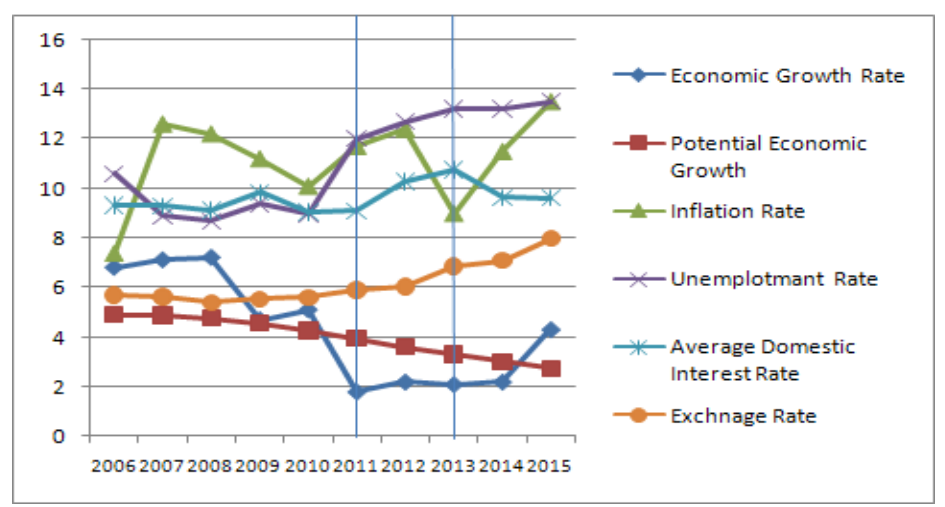

Figure 10. Attitude of macroeconomic variables

Source: Authors calculations based on data extracted from Ministry of Finance, The Financial Monthly Report, different editions and World Bank statistics on the internet.

Regression analysis of economic growth rate, inflation rate, unemployment rate and exchange rate (as dependent variables) and political risk components (as independent or explanatory variables) may accurately explain effects of political changes on these macroeconomic variables. The outcomes of the regression analysis were as follows. See Appendix 15, 16, 17 and 18.

- Economic growth rate is positively related to voice and accountability and control of corruption sub-indicators $[\mathrm{R}-\mathrm{Sq}=84.8 \% \mathrm{R}-\mathrm{Sq}(\mathrm{adj})=81.7 \%, \mathrm{~F}$ statistic is 27.83 with $\mathrm{p}$-value 0.000$]$.

- Unemployment rate is negatively related to voice and accountability and control of corruption indicators $[\mathrm{R}-\mathrm{Sq}=70.1 \% \mathrm{R}-\mathrm{Sq}(\mathrm{adj})=64.1 \%, \mathrm{~F}$ statistic is 11.7 with $\mathrm{p}$-value 0.002$]$.

- Political risks' sub-indicators are statistically insignificant independent predictors of both inflation rates [F statistic is 1.99 with p-value 0.196] and exchange rates [F statistic is 1.09 with p-value 0.444].

The first and second findings of the statistical analysis are interconnected, as there is usually a negative relationship between economic growth rate and unemployment rate especially when economic growth rates are below their potential levels. Thus, if improvement of voice and accountability and control of corruption indicators is able to stimulate economic growth rate to increase; then this may mean a decrease in the rate of unemployment. These two findings are consistent with the attitude of economic growth rate and unemployment rate through periods of political instability illustrated in Figure 10. 
The statistical analysis confirmed that fluctuations in inflation rates can't be explained by political changes. The only statistical finding which is inconsistent with observations of Figure 10 is that changes in exchange rates can't be explained by changes in political risk indicators. This finding can be attributed to the nature of sources of foreign exchange in Egypt, such as returns of tourism sector and foreign investment flows, which have been negatively affected by revolutions. These sources of foreign exchange take time to be restored, thus the negative effect resulting from the loss of foreign exchange extends even after regaining of political stability.

In spite that changes in exchange rate of Egyptian pound cannot be explained by changes in political risks' sub-indicators; however, there is a statistically significant negative relationship between depreciation of Egyptian pound exchange rate and political risk index $[\mathrm{R}-\mathrm{Sq}=36.2 \% \mathrm{R}-\mathrm{Sq}(\mathrm{adj})=30.4 \%$, F statistic is 6.25 with $\mathrm{p}$-value 0.029]. See Appendix 19. Thus, improvement in political risk index is able to appreciate the exchange rate of the Egyptian pound.

The effect of political risk on economic growth revealed a structural problem in the process of economic growth in Egypt. Figure 11 illustrates this structural problem as follows:

- Economic growth is positively related to both voice and accountability and control of corruption indicators; thus, improvement in these two political risks' sub-indicators stimulates economic growth to increase.

- Voice and accountability indicator is highly and positively correlated to three sub-indicators: political stability and absence of violence, regulatory quality and rule of law indicators.

- Both political stability and absence of violence and rule of law indicators are highly and negatively related to control of corruption indicator; thus, spread of corruption reduce the level of risk that is related to political stability and absence of violence and rule of law indicators; and hence improve voice and accountability risk indicator, and ultimately support the process of economic growth.

These findings reflect a paradox and malfunction in the economic growth process in Egypt. On one side, the process of economic growth has a positive direct relationship with control of corruption indicator and at the same time a negative indirect relationship with the same indicator. On the other side, it appears that corruption is pervasive in the structure of the Egyptian economy, as the process of economic growth is supported by spreading of corruption. This may explain why economic growth process in Egypt, even ones with high growth rates, did not manage to turn into a successful economic development process. The negative relationship between control of corruption indicator and average annual return of EGX30 boosts this finding, as spread of corruption promotes annual return on EGX30.

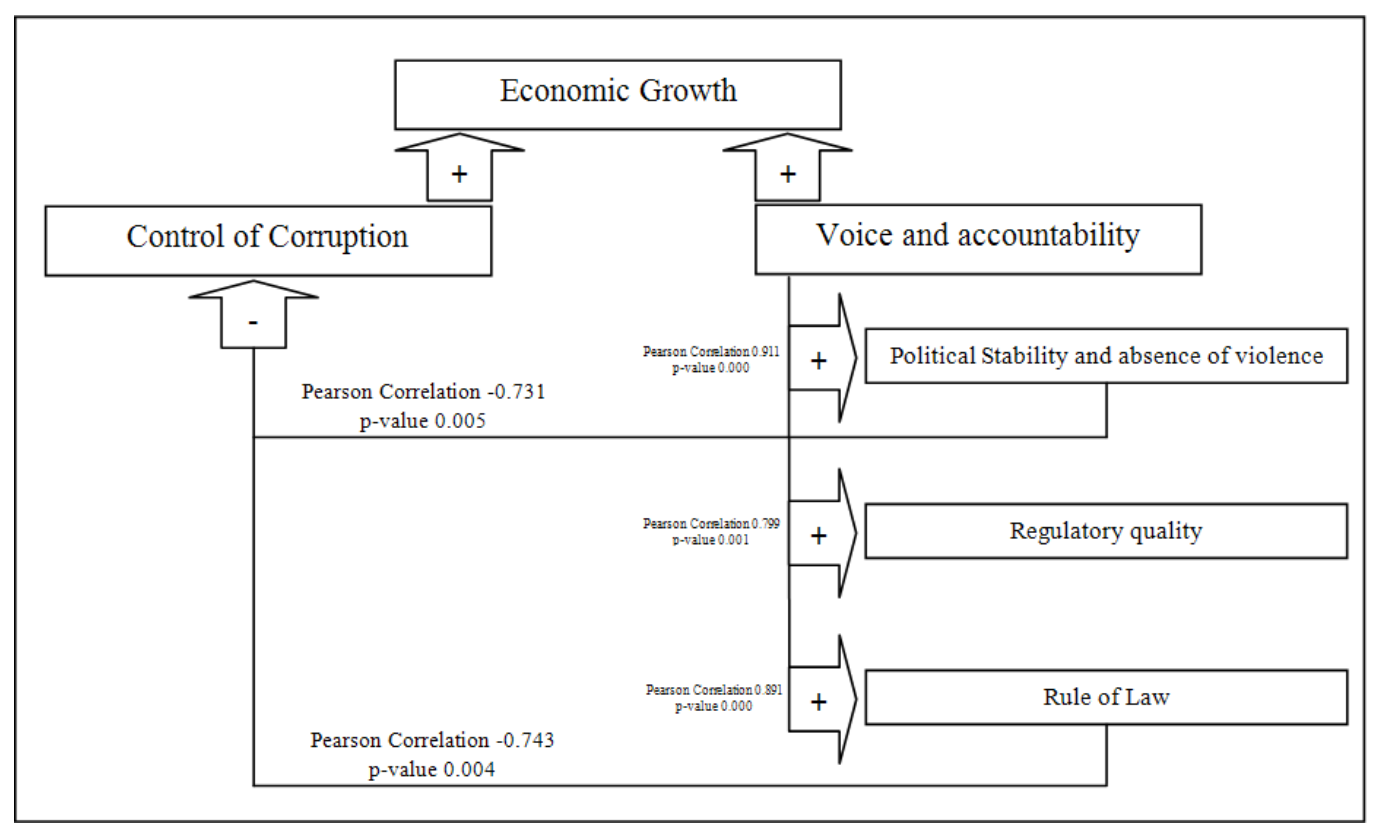

Figure 11. Political risks' sub-indicators and economic growth process in Egypt

Source: Table 1 and Appendix 11. 


\section{Concluding Remarks}

1). Political changes that started in Egypt on $25^{\text {th }}$ of January 2011 have led to deterioration of political risk index of Egypt and increased the level of country risk. This proves the validity of the first hypothesis of the study.

2). Political risks' sub-indicators are highly correlated which makes political risk index more elastic to changes in its sub-indicators.

3). In spite that political risks' sub-indicators are supportive to each other, as they are positively related to each other; however, control of corruption indicator works against all other political risks' indicators, as it is negatively related to political stability and rule of law indicators.

4). Political risk affects Egyptian Exchange in two ways; on one hand, voice and accountability, regulatory quality, and control of corruption indicators are positively related to value of traded stocks. On the other hand, in spite daily returns on EGX30 don't respond to changes in the level of political risk; however, annual returns on EGX30 do respond, as annual returns on EGX30 are negatively related to control of corruption. This proves the validity of the second hypothesis of the study.

5). The effect of political risk on portfolio investment net flows is greater than their effect on foreign direct investment net flows. Moreover, changes in foreign direct investment flows are inelastic to changes in the level of political risk.

6). Net flows of foreign direct investment are positively related to two sub-indicators of political risk index, voice and accountability; and control of corruption.

7). Average domestic interest rate in Egypt tends to increase during periods of internal and external shocks; however, responsiveness of domestic interest rate to internal shocks is relatively greater than its responsiveness to external shocks. Moreover, domestic interest rates are more vulnerable during periods of political changes and financial crises.

8). Interest rate on treasury bills is the most responsive interest rate to political changes, as it tends to increase with high levels of political risk. Political stability and absence of violence is the main indicator of political risk index that explains changes in interest rate on treasury bills, where deterioration of this sub-indicator leads to increase interest rates on treasury bills.

9). Interest rates on government securities are function of risk premiums that mainly result from political instability. This explains the aggravation of domestic public debt and its interest payments in Egypt after January revolution, as domestic debt and interest payments on debt increased by $180 \%$ and $171 \%$ respectively in the wake of $25^{\text {th }}$ of January revolution. Where deterioration of political stability and absence of violence indicator is responsible for the increase in interest rates on government securities; then it is responsible for aggravation of both domestic public debt and burdens of serving this debt. This proves the validity of the third hypothesis of the study.

10). Changes in the level of political risk is completely responsible for changes in macroeconomic variables either directly or indirectly. Improvement in political risk index, in general, and voice and accountability and control of corruption sub-indicators, in particular, has the power to stimulate economic growth and mitigate unemployment problem. While the effect of political risk on exchange rate can't be explained statistically due to the nature of foreign exchange sources in Egypt; however, it is clear that the increase in level of political risk, as a result of political changes, is the turning point for the decline in foreign exchange earnings and depreciation of Egyptian pound. Because of the strong positive relationship between deterioration of exchange rates and the increase in inflation rates, it can be said that political risk is indirectly responsible for occurrence of price inflation.

11). Spread of corruption is a main backer of the process of economic growth in Egypt, which explains failure of economic growth process to turn into a successful economic development one. This proves the validity of the fourth hypothesis of the study.

Figure 12 summarizes the effect of political risk index and its sub-indicators on Egyptian economy. Political risk affects macroeconomic goals directly and indirectly. The direct effect of political risk on macroeconomic goals is through its effects on economic growth and employment; where the indirect one is through political risk effects on exchange rates, domestic interest rates, domestic public debt, foreign direct investment and Egyptian Exchange. 


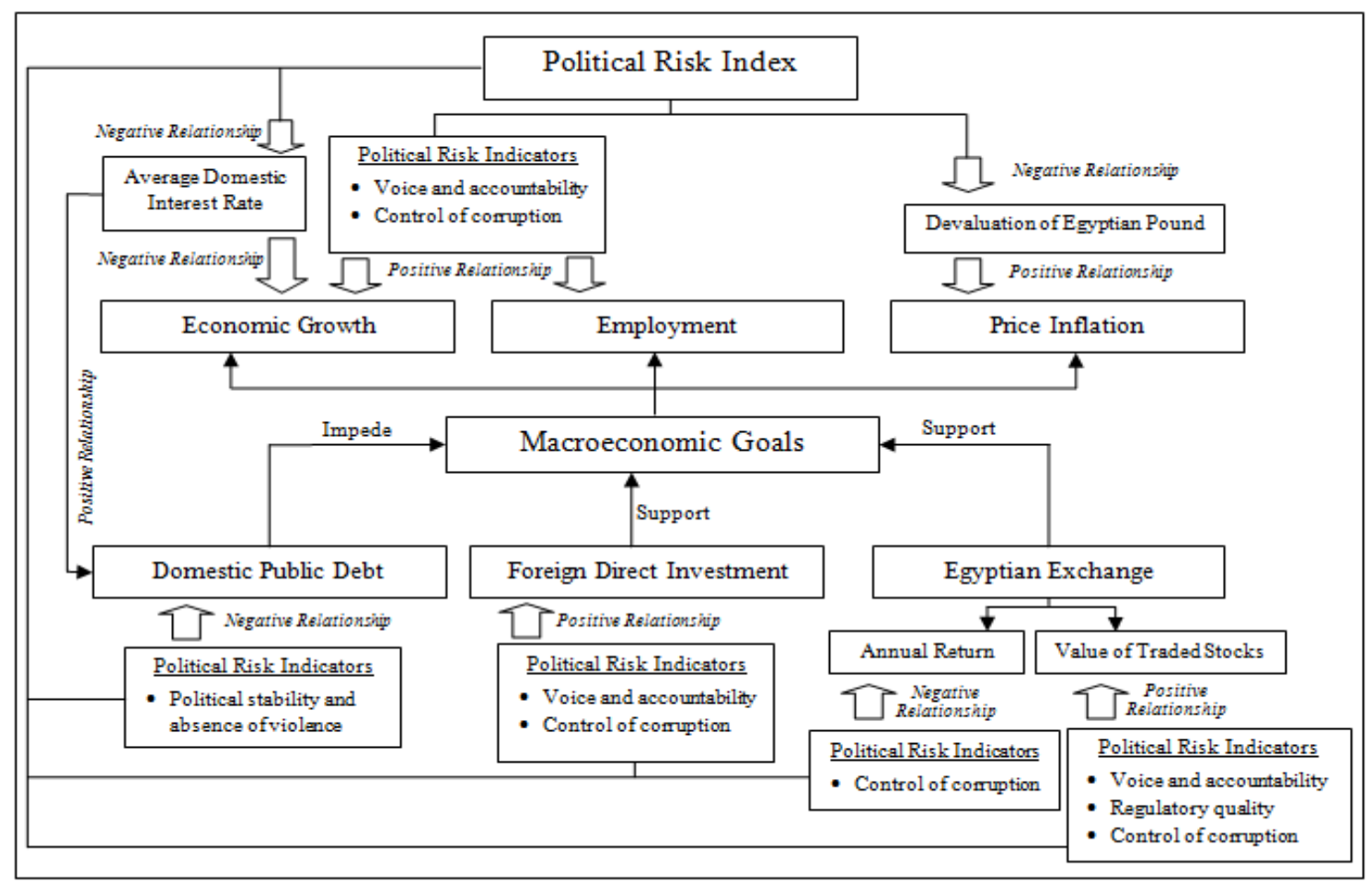

Figure 12. The effect of political risk index and its sub-indicators on the Egyptian economy

\section{Research Recommendations}

1). Adding new financial instruments to Egyptian financial market such as financial derivatives and stock options, where these financial instruments are able to decrease risks through hedging process.

2). Reactivation of foreign traders' fund transfers, as this has a great effect in facilitating the movement of capital to and from the Egyptian Exchange.

3). Separating military and politics, increasing democracy and controlling corruption have the power to increase foreign direct investment flows, economic growth rate and to alleviate the problem of unemployment.

4). Achieving government stability; mitigating internal and external conflicts, and ethnic and religious tensions have the power to contain inflation of domestic public debt.

5). Improving political risk index, through improving its sub-indicators, may help in restoring sources of foreign exchange and to appreciate Egyptian pound exchange rate which is negatively related to inflation rate.

6). Get rid of the pattern of economic growth that is based on corruption is a must for turning the process of economic growth into a successful economic development process. In this context, fighting against all forms of corruption will be the first step of a successful economic development process; although, this may increase the level of political risk in the short-run. Thus, it is a good chance to fight against corruption during periods of revolutions where the level of political risk is already high, and start a new process of economic growth that support economic development goals.

\section{References}

Andrade, S. C. (2009). A model of asset pricing under country risk. Journal of International Money and Finance, 28(4), 671-695. http://dx.doi.org/10.1016/j.jimonfin.2008.12.014

Andrea, B., \& Alexei, J. (2005). Inflation Risk Premium and the expectations hypothesis. Journal of Financial Economics, 75. http://dx.doi.org/10.1016/j.jfineco.2004.07.003

Andrew, A., \& Monika, P. (2003). A no-arbitrage vector auto-regression of term structure dynamics with macroeconomic and latent variables. Journal of Monetary Economics, 50. http://dx.doi.org/10.1016/S03043932(03)00032-1

Apergis, N. (2015). Policy risks, technological risks and stock returns: New evidence from the US stock market. Economic Modelling, 51, 359-365. http://dx.doi.org/10.1016/j.econmod.2015.08.021 
Bekaert, G., Harvey, C. R., Lundblad, C. T., \& Siegel, S. (2015). Political Risk and International Valuation. Journal of Corporate Finance. http://dx.doi.org/10.1016/j.jcorpfin.2015.12.007

Bilson, C. M., Brailsford, T. J., \& Hooper, V. C. (2002). The explanatory power of political risk in emerging markets. International Review of Financial Analysis, 11(1), 1-27. http://dx.doi.org/10.1016/S10575219(01)00067-9

Black, F. (1972). Capital market equilibrium with restricted borrowing. The Journal of Business, 45(3), 444-455.

Caporale, B., \& Caporale, T. (2008). Political risk and the expectations hypothesis. Economics Letters, 100(2), 178-180. http://dx.doi.org/10.1016/j.econlet.2008.01.007

Dimic, N., Vitaly, O., \& Vanja, P. (2015). The political risk factor in emerging, frontier, and developed stock markets. Finance Research Letters, 15, 239-245. http://dx.doi.org/10.1016/j.frl.2015.10.007

Egger, P., \& Winner, H. (2005). Evidence on corruption as an incentive for foreign direct investment. European Journal of Political Economy, 21, 932-952. http://dx.doi.org/10.1016/j.ejpoleco.2005.01.002

Enrico, C. P., \& Pieter, V. O. (2001). Privatization, political risk and stock market development in emerging economies. Journal of International Money and Finance, 20.

Eugene, F. F., \& Kenneth, R. F. (1989). Business Conditions and Expected Returns on Stocks and Bonds. Journal of Financial Economics, 25. http://dx.doi.org/10.1016/0304-405X(89)90095-0

Fama, E. F., \& French, K. R. (1995). Size and Book-to-Market Factors in Earnings and Returns. Journal of Finance, 50. http://dx.doi.org/10.1111/j.1540-6261.1995.tb05169.x

Fama, E. F., \& French, K. R. (2013). A Five-Factor Asset Pricing Model. Work paper, Available at SSRN: 2287202.

Fernandez-Perez, F., Fernández-Rodríguez, F., \& Sosvilla-Rivero, S. (2014). The term structure of interest rates as predictor of stock returns: Evidence for the IBEX 35 during a bear market. International Review of Economics and Finance, 31. http://dx.doi.org/10.1016/j.iref.2013.12.004

Frankie, C., Rataporn, D., \& Jun, W. (2014). Political uncertainty and stock market volatility in the Middle East and North African (MENA) Countries. Journal of International Financial Markets, Institutions \& Money, 28. http://dx.doi.org/10.1016/j.intfin.2013.10.008

Hans-Joachim, V. (2002). Stock Price Volatility and Political Uncertainty: Evidence from the Interwar Period (February 2002). MIT Department of Economics Working Paper No. 02-09; AFA 2003 Washington, DC Meetings. http://dx.doi.org/10.2139/ssrn.302926

Harvey, C. R. (1991). The world price of covariance risk. The Journal of Finance, 46(1), 111-157. http://dx.doi.org/10.1111/j.1540-6261.1991.tb03747.x

Heikki, L., \& Kari, H. (2015). Democracy, political risks and stock market performance. Journal of International Money and Finance, 59, 2015. http://dx.doi.org/10.1016/j.jimonfin.2015.06.002

Howard, K. (2015). Macroeconomic linkages between monetary policy and the term structure of interest rates. Journal of Financial Economics, 115. http://dx.doi.org/10.1016/j.jfineco.2014.09.006

Huang, T., Wu, F., Yu, J., \& Zhang, B. (2015). International political risk and government bond pricing. Journal of Banking \& Finance, 55, 393-405. http://dx.doi.org/10.1016/j.jbankfin.2014.08.003

Lehkonen, H., \& Heimonen, K. (2015). Democracy, political risks and stock market performance. Journal of International Money and Finance, 59, 77-99. http://dx.doi.org/10.1016/j.jimonfin.2015.06.002

Lintner, J. (1965). Security Prices, Risk, and Maximal Gains from Diversification. Journal of Finance, 20(4). http://dx.doi.org/10.1111/j.1540-6261.1965.tb02930.x

Liu, T., Hammoudeh, S., \& Thompson, M. A. (2013). A momentum threshold model of stock prices and country risk ratings: Evidence from BRICS countries. Journal of International Financial Markets, Institutions and Money, 27, 99-112. http://dx.doi.org/10.1016/j.intfin.2013.07.013

Llewellyn, D. H. (n. d.). International Country Risk Guide Methodology and Data. The PRS Group on the internet.

Markowitz, H. (1952). Portfolio selection. The Journal of Finance, 7(1). http://dx.doi.org/10.1111/j.15406261.1952.tb01525.x

Matthias, B., \& Carsten, H. (2007). Political risk, institutions and foreign direct investment. European Journal of 
Political Economy, 23, 397-415. http://dx.doi.org/10.1016/j.ejpoleco.2006.02.003

Ministry of Finance, The Financial Monthly Report, different editions.

Nebojsa, D., Vitaly, O., \& Vanja, P. (2015). The political risk factor in emerging, frontier, and developed stock markets. Finance Research Letters, 15. http://dx.doi.org/10.1016/j.frl.2015.10.007

Olga, K., Natalya, V., \& Tatiana, Z. (2014). Foreign direct investment and governance quality in Russia. Journal of Comparative Economics, 42. http://dx.doi.org/10.1016/j.jce.2014.08.001

Ross, S. (1976). The Arbitrage Theory of Capital Asset Pricing. Journal of Economic Theory, 13, 341-360. http://dx.doi.org/10.1016/0022-0531(76)90046-6

Sharpe, W. F. (1964). Capital Asset Prices A Theory of Market Equilibrium under Conditions of Risk. Journal of Finance, 19. http://dx.doi.org/10.1111/j.1540-6261.1964.tb02865.x

Smimou, K. (2014). International portfolio choice and political instability risk: A multi-objective approach. European Journal of Operational Research, 234(2), 546-560. http://dx.doi.org/10.1016/j.ejor.2013.01.024

Sultan, A. A. (2008). The Global Financial Crisis and its Implications for Egypt. Egyptian Center for Economic Studies, working paper No. 142.

Tao, H., Fei, W., Jing, Y., \& Bohui, Z. (2015). International political risk and government bond pricing. Journal of Banking \& Finance, 55. http://dx.doi.org/10.1016/j.jbankfin.2014.08.003

The Egyptian Cabinet, Information and Decision Support Center. Data on the internet.

Tomasz, P. W., \& Saima, K. P. (2014). Political environment and foreign direct investment: Evidence from OECD countries. European Journal of Political Economy, 36. http://dx.doi.org/10.1016/j.ejpoleco.2014.07.004

Vortelinos, D., \& Saha, S. (2016). The impact of political risk on return, volatility and discontinuity: Evidence from the international stock and foreign exchange markets. Finance Research Letters (In Press, Accepted Manuscript, Available online 17 March 2016). http://dx.doi.org/10.1016/j.frl.2016.03.017

World Bank statistics on the internet.

Yue-cheong, C., \& John Wei, K. C. (1996). Political risk and stock price volatility: The case of Hong Kong. Pacific-Basin Finance Journal, 4.

\section{Appendix}

\section{Appendix 1}

\begin{tabular}{|c|c|c|c|c|c|}
\hline \multicolumn{6}{|c|}{$\begin{array}{l}\mathrm{Y}=\text { Annul returns on EGX30. } \\
\mathrm{X}_{6}=\text { Control of corruption. }\end{array}$} \\
\hline \multicolumn{6}{|c|}{ Regression equation after applying stepwise method is } \\
\hline \multicolumn{6}{|c|}{$\mathrm{Y}=366-1060 \mathrm{X} 6$} \\
\hline Predictor & Coef & SE Coef & $\mathrm{T}$ & $\mathrm{P}$ & \\
\hline Constant & 365.9 & 109.1 & 3.35 & 0.006 & \\
\hline X6 & -1060.1 & 351.7 & -3.01 & 0.012 & \\
\hline$S=48.7694$ & $\mathrm{R}-\mathrm{Sq}=45.2 \%$ & \multicolumn{4}{|c|}{$\mathrm{R}-\mathrm{Sq}(\mathrm{adj})=40.3 \%$} \\
\hline \multicolumn{6}{|c|}{ Analysis of Variance } \\
\hline Source & $\mathrm{DF}$ & SS & MS & $\mathrm{F}$ & $\mathrm{P}$ \\
\hline Regression & 1 & 21610 & 21610 & 9.09 & 0.012 \\
\hline Residual Error & 11 & 26163 & 2378 & & \\
\hline Total & 12 & 47773 & & & \\
\hline
\end{tabular}




\section{Appendix 2}

Effect of political risks' sub-indicators on the value of traded stocks

$\mathrm{Y}=$ Values of traded stocks.

$\mathrm{X}_{1}=$ Voice and accountability.

$\mathrm{X}_{6}=$ Control of corruption.

Regression equation after applying stepwise method is

$\mathrm{Y}=-1.04 \mathrm{E}+12+8.63 \mathrm{E}+11 \mathrm{X}_{1}+2.86 \mathrm{E}+12 \mathrm{X}_{6}$

\begin{tabular}{cccccc}
\hline Predictor & Coef & SE Coef & $\mathrm{T}$ & $\mathrm{P}$ & \\
\hline Constant & $-1.04110 \mathrm{E}+12$ & $1.52770 \mathrm{E}+11$ & -6.81 & 0.000 & \\
$\mathrm{X}_{1}$ & $8.63307 \mathrm{E}+1$ & $1.65865 \mathrm{E}+11$ & 5.20 & 0.000 & \\
$\mathrm{X}_{6}$ & $2.85963 \mathrm{E}+12$ & $3.63076 \mathrm{E}+11$ & 7.88 & 0.000 & \\
$\mathrm{~S}=42399620605$ & $\mathrm{R}-\mathrm{Sq}=86.4 \%$ & $\mathrm{R}-\mathrm{Sq}(\mathrm{adj})=83.6 \%$ & & & \\
\hline Analysis of Variance & & & & & \\
\hline Source & $\mathrm{DF}$ & $\mathrm{SS}$ & $\mathrm{MS}$ & $\mathrm{F}$ & \\
\hline Regression & 2 & $1.13841 \mathrm{E}+23$ & $5.69206 \mathrm{E}+22$ & 31.66 & \\
Residual Error & 10 & $1.79773 \mathrm{E}+22$ & $1.79773 \mathrm{E}+21$ & & \\
Total & 12 & $1.31818 \mathrm{E}+23$ & & & \\
\hline
\end{tabular}

\section{Appendix 3}

Responsiveness of foreign traders (Arabs) in stock market to political risks' sub-indicators

$\mathrm{Y}=$ Values of traded stocks by Arabs.

$\mathrm{X}_{1}=$ Voice and accountability.

$\mathrm{X}_{6}=$ Control of corruption.

Regression equation after applying stepwise method is

$\mathrm{Y}=-1.17 \mathrm{E}+11+1.11 \mathrm{E}+11 \mathrm{X}_{1}+2.98 \mathrm{E}+11 \mathrm{X}_{6}$

\begin{tabular}{|c|c|c|c|c|c|}
\hline Predictor & Coef & SE Coef & $\mathrm{T}$ & $\mathrm{P}$ & \\
\hline Constant & $-1.17078 \mathrm{E}+11$ & 19354975306 & -6.05 & 0.000 & \\
\hline $\mathrm{X}_{1}$ & $1.11018 \mathrm{E}+11$ & 21014054262 & 5.28 & 0.000 & \\
\hline $\mathrm{X}_{6}$ & $2.97751 \mathrm{E}+11$ & 45999503984 & 6.47 & 0.000 & \\
\hline $\mathrm{S}=5371764996$ & $\mathrm{R}-\mathrm{Sq}=82.3 \%$ & $\mathrm{R}-\mathrm{Sq}(\operatorname{adj})=78.7 \%$ & & & \\
\hline \multicolumn{6}{|l|}{ Analysis of Variance } \\
\hline Source & $\mathrm{DF}$ & SS & MS & $\mathrm{F}$ & $\mathrm{P}$ \\
\hline Regression & 2 & $1.33971 \mathrm{E}+21$ & $6.69855 \mathrm{E}+20$ & 23.21 & 0.000 \\
\hline Residual Error & 10 & $2.88559 \mathrm{E}+20$ & $2.88559 \mathrm{E}+19$ & & \\
\hline Total & 12 & $1.62827 \mathrm{E}+21$ & & & \\
\hline
\end{tabular}

\section{Appendix 4}

Responsiveness of foreign traders (Non-Arabs) in stock market to political risks' sub-indicators

$\mathrm{Y}=$ Values of traded stocks by non-Arabs foreigners.

$\mathrm{X}_{1}=$ Voice and accountability.

$\mathrm{X}_{6}=$ Control of corruption.

Regression equation after applying stepwise method is

$\mathrm{Y}=-1.87 \mathrm{E}+11+1.48 \mathrm{E}+11 \mathrm{X}_{1}+5.23 \mathrm{E}+11 \mathrm{X}_{6}$

\begin{tabular}{cccccc}
\hline Predictor & Coef & SE Coef & T & P & \\
\hline Constant & $-1.86675 \mathrm{E}+11$ & 32743594923 & -5.70 & 0.000 & \\
$\mathrm{X}_{1}$ & $1.47695 \mathrm{E}+11$ & 35550325928 & 4.15 & 0.002 & \\
$\mathrm{X}_{6}$ & $5.23113 \mathrm{E}+11$ & 77819222256 & 6.72 & 0.000 & \\
$\mathrm{~S}=9087632211$ & $\mathrm{R}-\mathrm{Sq}=82.0 \%$ & $\mathrm{R}-\mathrm{Sq}(\mathrm{adj})=78.4 \%$ & & & \\
\hline Analysis of Variance & & & & & \\
\hline Source & $\mathrm{DF}$ & $\mathrm{SS}$ & $\mathrm{MS}$ & $\mathrm{F}$ & $\mathrm{P}$ \\
\hline Regression & 2 & $3.76441 \mathrm{E}+21$ & $1.88221 \mathrm{E}+21$ & 22.79 & 000 \\
Residual Error & 10 & $8.25851 \mathrm{E}+20$ & $8.25851 \mathrm{E}+19$ & & \\
Total & 12 & $4.59026 \mathrm{E}+21$ & & & \\
\hline
\end{tabular}




\section{Appendix 5}

Responsiveness of Egyptian traders in stock market to political risks' sub-indicators $\mathrm{Y}=$ Values of traded stocks by Egyptians.

$\mathrm{X}_{4}=$ Voice and accountability.

$\mathrm{X}_{6}=$ Control of corruption.

Regression equation after applying stepwise method is

$\mathrm{Y}=-1.62 \mathrm{E}+12+2.42 \mathrm{E}+12 \mathrm{X}_{4}+1.76 \mathrm{E}+12 \mathrm{X}_{6}$

\begin{tabular}{|c|c|c|c|c|c|}
\hline Predictor & Coef & SE Coef & $\mathrm{T}$ & $\mathrm{P}$ & \\
\hline Constant & $-1.61941 \mathrm{E}+12$ & $2.86689 \mathrm{E}+11$ & -5.65 & 0.000 & \\
\hline $\mathrm{X}_{4}$ & $2.41764 \mathrm{E}+12$ & $5.08245 \mathrm{E}+11$ & 4.76 & 0.001 & \\
\hline $\mathrm{X}_{6}$ & $1.76458 \mathrm{E}+12$ & $2.53070 \mathrm{E}+11$ & 6.97 & 0.000 & \\
\hline$S=32671233838$ & $\mathrm{R}-\mathrm{Sq}=84.4 \%$ & $R-S q(\operatorname{adj})=81.3 \%$ & & & \\
\hline \multicolumn{6}{|l|}{ Analysis of Variance } \\
\hline Source & $\mathrm{DF}$ & SS & MS & $\mathrm{F}$ & $\mathrm{P}$ \\
\hline Regression & 2 & $5.79153 \mathrm{E}+22$ & $2.89577 \mathrm{E}+22$ & 27.13 & 0.000 \\
\hline Residual Error & 10 & $1.06741 \mathrm{E}+22$ & $1.06741 \mathrm{E}+21$ & & \\
\hline Total & 12 & $6.85894 \mathrm{E}+22$ & & & \\
\hline
\end{tabular}

\section{Appendix 6}

Effect of political risks sub-indicators on foreign direct investment net flows

$\mathrm{Y}=$ Net flows of foreign direct investment.

$\mathrm{X}_{1}=$ Voice and accountability.

$\mathrm{X}_{6}=$ Control of corruption.

\begin{tabular}{|c|c|c|c|c|c|}
\hline \multicolumn{6}{|c|}{$\begin{array}{l}\text { Regression equation after applying stepwise method is } \\
Y=-39244+34492 X_{1}+103489 X_{6}\end{array}$} \\
\hline Predictor & Coef & SE Coef & $\mathrm{T}$ & $\mathrm{P}$ & \\
\hline Constant & -39244 & 7017 & -5.59 & 0.000 & \\
\hline $\mathrm{X}_{1}$ & 34492 & 7619 & 4.53 & 0.001 & \\
\hline $\mathrm{X}_{6}$ & 103489 & 16678 & 6.21 & 0.000 & \\
\hline$S=1947.61$ & $\mathrm{R}-\mathrm{Sq}=80.2 \%$ & $R-S q(\operatorname{adj})=76.2 \%$ & & & \\
\hline \multicolumn{6}{|l|}{ Analysis of Variance } \\
\hline Source & DF & SS & MS & $\mathrm{F}$ & $\mathrm{P}$ \\
\hline Regression & 2 & 153510298 & 76755149 & 20.24 & 0.000 \\
\hline Residual Error & 10 & 37931768 & 3793177 & & \\
\hline Total & 12 & 191442066 & & & \\
\hline
\end{tabular}

\section{Appendix 7}

Effect of political risks sub-indicators on changes in foreign direct investment net flows

* X3 is (essentially) constant

* X3 has been removed from the equation (government effectiveness).

$\mathrm{Y}=$ Changes in foreign direct investment net flows.

$\mathrm{X}_{1}=$ Voice and accountability.

$\mathrm{X}_{2}=$ Political stability and absence of violence.

$\mathrm{X}_{4}=$ Regulatory quality.

$\mathrm{X}_{5}=$ Rule of law.

$\mathrm{X}_{6}=$ Control of corruption.

Regression equation is

$\mathrm{Y}=-12115-1779 \mathrm{X}_{1}+18367 \mathrm{X}_{2}+701 \mathrm{X}_{4}-8035 \mathrm{X}_{5}+11469 \mathrm{X}_{6}$

\begin{tabular}{ccccc}
\hline Predictor & Coef & SE Coef & $\mathrm{T}$ & $\mathrm{P}$ \\
\hline Constant & -12115 & 43018 & -0.28 & 0.786 \\
$\mathrm{X}_{1}$ & -1779 & 33289 & -0.05 & 0.959 \\
$\mathrm{X}_{2}$ & 18367 & 54994 & 0.33 & 0.748 \\
$\mathrm{X}_{4}$ & 701 & 92259 & 0.01 & 0.994 \\
$\mathrm{X}_{5}$ & -8035 & 66985 & -0.12 & 0.908 \\
$\mathrm{X}_{6}$ & 11469 & 44880 & 0.26 & 0.806 \\
$\mathrm{~S}=3546.59$ & $\mathrm{R}-\mathrm{Sq}=10.0 \%$ & $\mathrm{R}-\mathrm{Sq}(\mathrm{adj})=0.0 \%$ & & \\
\hline
\end{tabular}




\begin{tabular}{cccccc}
\hline Analysis of Variance & & & & \\
Source & DF & SS & MS & F & P \\
Regression & 5 & 9771298 & 1954260 & 0.16 & 0.971 \\
Residual Error & 7 & 88048205 & 12578315 & & \\
Total & 12 & 97819503 & & & \\
\hline
\end{tabular}

\section{Appendix 8}

Effect of political risks sub-indicators on portfolio investment net flows

$* \mathrm{X}_{3}$ is (essentially) constant

$* \mathrm{X}_{3}$ has been removed from the equation (government effectiveness).

$\mathrm{Y}=$ Portfolio investment net flows.

$\mathrm{X}_{1}=$ Voice and accountability.

$\mathrm{X}_{2}=$ Political stability and absence of violence.

$\mathrm{X}_{4}=$ Regulatory quality.

$\mathrm{X}_{5}=$ Rule of law.

$\mathrm{X}_{6}=$ Control of corruption .

\begin{tabular}{|c|c|c|c|c|c|}
\hline \multicolumn{6}{|c|}{ Regression equation is } \\
\hline Predictor & Coef & SE Coef & $\mathrm{T}$ & $\mathrm{P}$ & \\
\hline Constant & -87434 & 46238 & -1.89 & 0.101 & \\
\hline $\mathrm{X}_{1}$ & -47926 & 35781 & -1.34 & 0.222 & \\
\hline $\mathrm{X}_{2}$ & -78690 & 59110 & -1.33 & 0.225 & \\
\hline $\mathrm{X}_{4}$ & 152305 & 99165 & 1.54 & 0.168 & \\
\hline $\mathrm{X}_{5}$ & 146509 & 71998 & 2.03 & 0.081 & \\
\hline $\mathrm{X}_{6}$ & 9350 & 48239 & 0.19 & 0.852 & \\
\hline $\mathrm{S}=3812.04$ & $\mathrm{R}-\mathrm{Sq}=47.3 \%$ & $\mathrm{R}-\mathrm{Sq}(\operatorname{adj})=9.7 \%$ & & & \\
\hline \multicolumn{6}{|c|}{ Analysis of Variance } \\
\hline Source & DF & SS & MS & $\mathrm{F}$ & $\mathrm{P}$ \\
\hline Regression & 5 & 91389432 & 18277886 & 1.26 & 0.377 \\
\hline Residual Error & 7 & 101721800 & 14531686 & & \\
\hline Total & 12 & 193111232 & & & \\
\hline
\end{tabular}

\section{Appendix 9}

Effect of political risks sub-indicators on changes in portfolio investment net flows

$* \mathrm{X}_{3}$ is (essentially) constant

$* \mathrm{X}_{3}$ has been removed from the equation (government effectiveness).

$\mathrm{Y}=$ Changes in portfolio investment net flows.

$\mathrm{X}_{1}=$ Voice and accountability.

$\mathrm{X}_{2}=$ Political stability and absence of violence.

$\mathrm{X}_{4}=$ Regulatory quality.

$\mathrm{X}_{5}=$ Rule of law.

$\mathrm{X}_{6}=$ Control of corruption.

Regression equation is

$Y=-141992-49848 X_{1}-218966 X_{2}+288363 X_{4}+311711 X_{5}+2166 X_{6}$

\begin{tabular}{|c|c|c|c|c|c|}
\hline Predictor & Coef & SE Coef & $\mathrm{T}$ & $\mathrm{P}$ & \\
\hline Constant & -141992 & 63428 & -2.24 & 0.060 & \\
\hline $\mathrm{X}_{1}$ & -49848 & 49084 & -1.02 & 0.344 & \\
\hline $\mathrm{X}_{2}$ & -218966 & 81086 & -2.70 & 0.031 & \\
\hline $\mathrm{X}_{4}$ & 288363 & 136032 & 2.12 & 0.072 & \\
\hline $\mathrm{X}_{5}$ & 311711 & 98766 & 3.16 & 0.016 & \\
\hline $\mathrm{X}_{6}$ & 2166 & 66173 & 0.03 & 0.975 & \\
\hline$S=5229.27$ & $\mathrm{R}-\mathrm{Sq}=64.0 \%$ & $\mathrm{R}-\mathrm{Sq}(\operatorname{adj})=38.3 \%$ & & & \\
\hline \multicolumn{6}{|l|}{ Analysis of Variance } \\
\hline Source & $\mathrm{DF}$ & SS & MS & $\mathrm{F}$ & $\mathrm{P}$ \\
\hline Regression & 5 & 340536767 & 68107353 & 2.49 & 0.133 \\
\hline Residual Error & 7 & 191416905 & 27345272 & & \\
\hline Total & 12 & 531953672 & & & \\
\hline
\end{tabular}




\section{Appendix 10}

Relationship between interest rate on short-term loans and political risks' sub-indicators

$\mathrm{Y}=$ Interest rate on short-term loans.

$\mathrm{X}_{2}=$ Political stability and absence of violence.

Regression equation after applying stepwise method is

$\mathrm{Y}=6.94+7.28 \mathrm{X}_{2}$

\begin{tabular}{ccccc}
\hline Predictor & Coef & SE Coef & T & P \\
\hline Constant & 6.939 & 1.069 & 6.49 & 0.000 \\
$\mathrm{X}_{2}$ & 7.276 & 1.402 & 5.19 & 0.000 \\
$\mathrm{~S}=0.492648$ & $\mathrm{R}-\mathrm{Sq}=71.0 \%$ & $\mathrm{R}-\mathrm{Sq}(\mathrm{adj})=68.4 \%$ & & \\
\hline Analysis of Variance & & & & $\mathrm{F}$ \\
\hline Source & $\mathrm{DF}$ & $\mathrm{SS}$ & $\mathrm{MS}$ & $\mathrm{P}$ \\
\hline Regression & 1 & 6.5402 & 6.5402 & 0.000 \\
Residual Error & 11 & 2.6697 & 0.2427 & \\
Total & 12 & 9.2099 & & \\
\hline
\end{tabular}

\section{Appendix 11}

Relationship between interest rate on deposits at post office and political risks' sub-indicators

$\mathrm{Y}=$ Interest rate on deposits at post office.

$\mathrm{X}_{6}=$ Control of corruption.

Regression equation after applying stepwise method is

$\mathrm{Y}=15.5-19.1 \mathrm{X}_{6}$

\begin{tabular}{ccccc}
\hline Predictor & Coef & SE Coef & $\mathrm{T}$ & $\mathrm{P}$ \\
\hline Constant & 15.5333 & 0.8235 & 18.86 & 0.000 \\
$\mathrm{X}_{6}$ & -19.133 & 2.656 & -7.20 & 0.000 \\
$\mathrm{~S}=0.368291$ & $\mathrm{R}-\mathrm{Sq}=82.5 \%$ & $\mathrm{R}-\mathrm{Sq}(\mathrm{adj})=80.9 \%$ & & \\
\hline Analysis of Variance & & & & $\mathrm{F}$ \\
\hline Source & $\mathrm{DF}$ & $\mathrm{SS}$ & $\mathrm{MS}$ & $\mathrm{P} 1.90$ \\
\hline Regression & 1 & 7.0401 & 7.0401 & 0.000 \\
Residual Error & 11 & 1.4920 & 0.1356 & \\
Total & 12 & 8.5321 & & \\
\hline
\end{tabular}

\section{Appendix 12}

Relationship between interest rate on treasury bills and political risks' sub-indicators

$\mathrm{Y}=$ Interest rate on treasury bills.

$\mathrm{X}_{2}=$ Political stability and absence of violence.

Regression equation after applying stepwise method is

$\mathrm{Y}=21.3-15.2 \mathrm{X}_{2}$

\begin{tabular}{|c|c|c|c|c|c|}
\hline Predictor & Coef & SE Coef & $\mathrm{T}$ & $\mathrm{P}$ & \\
\hline Constant & 21.317 & 2.871 & 7.42 & 0.000 & \\
\hline $\mathrm{X}_{2}$ & -15.153 & 3.763 & -4.03 & 0.002 & \\
\hline $\mathrm{S}=1.32270$ & $\mathrm{R}-\mathrm{Sq}=59.6 \%$ & $\mathrm{R}-\mathrm{Sq}(\operatorname{adj})=55.9 \%$ & & & \\
\hline \multicolumn{6}{|l|}{ Analysis of Variance } \\
\hline Source & DF & $\mathrm{SS}$ & MS & $\mathrm{F}$ & $\mathrm{P}$ \\
\hline Regression & 1 & 28.367 & 28.367 & 16.21 & 0.002 \\
\hline Residual Error & 11 & 19.245 & 1.750 & & \\
\hline Total & 12 & 47.612 & & & \\
\hline
\end{tabular}




\section{Appendix 13}

Effect of political risk on domestic public debt

$\mathrm{Y}=$ Domestic public debt.

$\mathrm{X}_{2}=$ Political stability and absence of violence.

Regression equation after applying stepwise method is

$\mathrm{Y}=3939-4110 \mathrm{X}_{2}$

\begin{tabular}{cccccc}
\hline Predictor & Coef & SE Coef & T & P & \\
\hline Constant & 3939.4 & 440.8 & 8.94 & 0.000 & \\
$\mathrm{X}_{2}$ & -4110.3 & 577.8 & -7.11 & 0.000 & \\
$\mathrm{~S}=203.073$ & $\mathrm{R}-\mathrm{Sq}=82.1 \%$ & $\mathrm{R}-\mathrm{Sq}(\mathrm{adj})=80.5 \%$ & & & \\
\hline Analysis of Variance & & & & $\mathrm{P}$ \\
\hline Source & $\mathrm{DF}$ & $\mathrm{SS}$ & $\mathrm{MS}$ & $\mathrm{F}$ & 0.000 \\
\hline Regression & 1 & 2087134 & 2087134 & 50.61 & \\
Residual Error & 11 & 453624 & 41239 & & \\
Total & 12 & 2540758 & & & \\
\hline
\end{tabular}

\section{Appendix 14}

Effect of political risk on interest payments on domestic public debt

$\mathrm{Y}=$ Interest payments on domestic public debt.

$\mathrm{X}_{2}=$ Political stability and absence of violence.

Regression equation after applying stepwise method is

$\mathrm{Y}=374-408 \mathrm{X}_{2}$

\begin{tabular}{cccccc}
\hline Predictor & Coef & SE Coef & $\mathrm{T}$ & $\mathrm{P}$ & \\
\hline Constant & 373.68 & 50.21 & 7.44 & 0.000 & \\
$\mathrm{X}_{2}$ & -408.27 & 65.81 & -6.20 & 0.000 & \\
$\mathrm{~S}=23.1322$ & $\mathrm{R}-\mathrm{Sq}=77.8 \%$ & $\mathrm{R}-\mathrm{Sq}(\mathrm{adj})=75.7 \%$ & & & \\
\hline Analysis of Variance & & & & $\mathrm{F}$ & 0.000 \\
\hline Source & $\mathrm{DF}$ & $\mathrm{SS}$ & $\mathrm{MS}$ & $\mathrm{F}$ & \\
\hline Regression & 1 & 20593 & 20593 & 38.48 & \\
Residual Error & 11 & 5886 & 535 & & \\
Total & 12 & 26479 & & & \\
\hline
\end{tabular}

\section{Appendix 15}

Effect of political risks' indicators on economic growth

$\mathrm{Y}=$ Economic growth rate.

$\mathrm{X}_{1}=$ Voice and accountability.

$\mathrm{X}_{6}=$ Control of corruption.

Regression equation after applying stepwise method is

$\mathrm{Y}=-16.4+24.3 \mathrm{X}_{1}+38.4 \mathrm{X}_{6}$

\begin{tabular}{cccccc}
\hline Predictor & Coef & SE Coef & T & $\mathrm{P}$ & \\
\hline Constant & -16.415 & 3.069 & -5.35 & 0.000 & \\
$\mathrm{X}_{1}$ & 24.298 & 3.332 & 7.29 & 0.000 & \\
$\mathrm{X}_{6}$ & 38.351 & 7.293 & 5.26 & 0.000 & \\
$\mathrm{~S}=0.851717$ & $\mathrm{R}-\mathrm{Sq}=84.8 \%$ & $\mathrm{R}-\mathrm{Sq}(\mathrm{adj})=81.7 \%$ & & & \\
\hline Analysis of Variance & & & & $\mathrm{P}$ & 0.000 \\
\hline Source & $\mathrm{DF}$ & $\mathrm{SS}$ & $\mathrm{MS}$ & 27.83 & \\
\hline Regression & 2 & 40.375 & 20.188 & & \\
Residual Error & 10 & 7.254 & 0.725 & & \\
Total & 12 & 47.629 & & & \\
\hline
\end{tabular}




\section{Appendix 16}

Effect of political risks' indicators on unemployment

$\mathrm{Y}=$ Unemployment rate.

$\mathrm{X}_{1}=$ Voice and accountability.

$\mathrm{X}_{6}=$ Control of corruption.

Regression equation after applying stepwise method is

$\mathrm{Y}=23.0-18.0 \mathrm{X}_{1}-18.5 \mathrm{X}_{6}$

\begin{tabular}{|c|c|c|c|c|c|}
\hline Predictor & Coef & SE Coef & $\mathrm{T}$ & $\mathrm{P}$ & \\
\hline Constant & 22.952 & 3.444 & 6.66 & 0.000 & \\
\hline $\mathrm{X}_{1}$ & -18.026 & 3.739 & -4.82 & 0.001 & \\
\hline $\mathrm{X}_{6}$ & -18.514 & 8.186 & -2.26 & 0.047 & \\
\hline $\mathrm{S}=0.955897$ & $\mathrm{R}-\mathrm{Sq}=70.1 \%$ & $\mathrm{R}-\mathrm{Sq}(\operatorname{adj})=64.1 \%$ & & & \\
\hline \multicolumn{6}{|l|}{ Analysis of Variance } \\
\hline Source & DF & SS & MS & $\mathrm{F}$ & $\mathrm{P}$ \\
\hline Regression & 2 & 21.380 & 10.690 & 11.70 & 0.002 \\
\hline Residual Error & 10 & 9.137 & 0.914 & & \\
\hline Total & 12 & 30.517 & & & \\
\hline
\end{tabular}

\section{Appendix 17}

Effect of political risks' indicators on price inflation

* X3 is (essentially) constant

* X3 has been removed from the equation.

$\mathrm{Y}=$ Inflation rate.

$\mathrm{X}_{1}=$ Voice and accountability.

$\mathrm{X}_{2}=$ Political stability and absence of violence.

$\mathrm{X}_{4}=$ Regulatory quality.

$\mathrm{X}_{5}=$ Rule of law.

$\mathrm{X}_{6}=$ Control of corruption.

\begin{tabular}{|c|c|c|c|c|c|}
\hline \multicolumn{6}{|c|}{ Regression equation is } \\
\hline \multicolumn{6}{|c|}{$Y=14.9+7.2 X_{1}+40.9 X_{2}-1.6 X_{4}-78.3 X_{5}+26.7 X_{6}$} \\
\hline Predictor & Coef & SE Coef & $\mathrm{T}$ & $\mathrm{P}$ & \\
\hline Constant & 14.88 & 30.06 & 0.49 & 0.636 & \\
\hline $\mathrm{X}_{1}$ & 7.20 & 23.27 & 0.31 & 0.766 & \\
\hline $\mathrm{X}_{2}$ & 40.89 & 38.43 & 1.06 & 0.323 & \\
\hline $\mathrm{X}_{4}$ & -1.61 & 64.48 & -0.02 & 0.981 & \\
\hline $\mathrm{X}_{5}$ & -78.27 & 46.81 & -1.67 & 0.138 & \\
\hline $\mathrm{X}_{6}$ & 26.74 & 31.37 & 0.85 & 0.422 & \\
\hline$S=2.47865$ & $\mathrm{R}-\mathrm{Sq}=58.8 \%$ & $\mathrm{R}-\mathrm{Sq}(\operatorname{adj})=29.3 \%$ & & & \\
\hline \multicolumn{6}{|c|}{ Analysis of Variance } \\
\hline Source & DF & SS & MS & $\mathrm{F}$ & $\mathrm{P}$ \\
\hline Regression & 5 & 61.283 & 12.257 & 1.99 & 0.196 \\
\hline Residual Error & 7 & 43.006 & 6.144 & & \\
\hline Total & 12 & 104.289 & & & \\
\hline
\end{tabular}




\section{Appendix 18}

Effect of political risks' indicators on exchange rate

* X3 is (essentially) constant

* X3 has been removed from the equation.

$\mathrm{Y}=$ Exchange rate.

$\mathrm{X}_{1}=$ Voice and accountability.

$\mathrm{X}_{2}=$ Political stability and absence of violence.

$\mathrm{X}_{4}=$ Regulatory quality.

$\mathrm{X}_{5}=$ Rule of law.

$\mathrm{X}_{6}=$ Control of corruption.

\begin{tabular}{|c|c|c|c|c|c|}
\hline \multicolumn{6}{|c|}{$\begin{array}{l}\text { Regression equation is } \\
\mathrm{Y}=5.13-3.38 \mathrm{X} 1-5.47 \mathrm{X} 2+13.6 \mathrm{X} 4+1.5 \mathrm{X} 5-4.78 \mathrm{X} 6\end{array}$} \\
\hline Predictor & Coef & SE Coef & $\mathrm{T}$ & $\mathrm{P}$ & \\
\hline Constant & 5.132 & 7.644 & 0.67 & 0.524 & \\
\hline $\mathrm{X}_{1}$ & -3.376 & 5.915 & -0.57 & 0.586 & \\
\hline $\mathrm{X}_{2}$ & -5.474 & 9.772 & -0.56 & 0.593 & \\
\hline $\mathrm{X}_{4}$ & 13.64 & 16.39 & 0.83 & 0.433 & \\
\hline $\mathrm{X}_{5}$ & 1.50 & 11.90 & 0.13 & 0.903 & \\
\hline $\mathrm{X}_{6}$ & -4.781 & 7.975 & -0.60 & 0.568 & \\
\hline$S=0.630211$ & $\mathrm{R}-\mathrm{Sq}=43.7 \%$ & $\mathrm{R}-\mathrm{Sq}(\operatorname{adj})=3.4 \%$ & & & \\
\hline \multicolumn{6}{|c|}{ Analysis of Variance } \\
\hline Source & DF & SS & MS & $\mathrm{F}$ & $\mathrm{P}$ \\
\hline Regression & 5 & 2.1549 & 0.4310 & 1.09 & 0.444 \\
\hline Residual Error & 7 & 2.7802 & 0.3972 & & \\
\hline Total & 12 & 4.9351 & & & \\
\hline
\end{tabular}

\section{Appendix 19}

Effect of political risk index on exchange rate

$\mathrm{Y}=$ Exchange rate.

$\mathrm{X}_{1}=$ Political risk index.

\begin{tabular}{|c|c|c|c|c|c|}
\hline \multicolumn{6}{|c|}{$\begin{array}{l}\text { Regression equation is } \\
Y=10.6-9.45 X_{1}\end{array}$} \\
\hline Predictor & Coef & SE Coef & $\mathrm{T}$ & $\mathrm{P}$ & \\
\hline Constant & 10.592 & 1.897 & 5.58 & 0.000 & \\
\hline $\mathrm{X}_{1}$ & -9.448 & 3.779 & -2.50 & 0.029 & \\
\hline$S=0.534844$ & $\mathrm{R}-\mathrm{Sq}=36.2 \%$ & $\mathrm{R}-\mathrm{Sq}(\mathrm{adj})=30.4 \%$ & & & \\
\hline \multicolumn{6}{|c|}{ Analysis of Variance } \\
\hline Source & DF & SS & MS & $\mathrm{F}$ & $\mathrm{P}$ \\
\hline Regression & 1 & 1.7885 & 1.7885 & 6.25 & 0.029 \\
\hline Residual Error & 11 & 3.1466 & 0.2861 & & \\
\hline Total & 12 & 4.9351 & & & \\
\hline
\end{tabular}

\section{Copyrights}

Copyright for this article is retained by the author(s), with first publication rights granted to the journal.

This is an open-access article distributed under the terms and conditions of the Creative Commons Attribution license (http://creativecommons.org/licenses/by/3.0/). 